\title{
AN INTERNATIONAL JOURNAL
}

Vol.:8 Issue:4 Year:2020, 647-684

\author{
Citation: Özbek, V., \& Koç, F., \& Doğan, Ö., Marka Aşkının Öncülleri ve Sonuçları: Akıllı \\ Telefon Ürünü Özelinde Bir Araştırma, BMIJ, (2020), 8(4): 647-684, doi: \\ http://dx.doi.org/10.15295/bmij.v8i4.1685
}

\section{MARKA AŞKININ ÖNCÜLLERİ VE SONUÇLARI: AKILLI TELEFON ÜRÜNÜ ÖZELİNDE BİR ARAŞTIRMA ${ }^{1}$}

Volkan ÖZBEK ${ }^{2}$
Fatih KOÇ ${ }^{3}$
Öykem DOĞAN 4

Çalıșmada ilk yazar Sorumlu Yazar (Corresponding Author) rolündedir. $\begin{array}{ll}\text { Received Date (Başvuru Tarihi): } & 12 / 11 / 2020 \\ \text { Accepted Date (Kabul Tarihi): } & 6 / 12 / 2020 \\ \text { Published Date (Yayın Tarihi): } & 10 / 12 / 2020\end{array}$
$\ddot{O Z Z}$

Anahtar Kelimeler:

Marka Aşkl,

Akıllı Telefon,

Sadakat,

Güven,

Memnuniyet

JEL Kodlar:

M30, M31
Bu çalışmanın amacl, tüketicilerin markaya olan güveni, markanın yenilikçiliğine olan inancı ve ilgilenim düzeylerinin marka aşkı üzerindeki etkisini tespit etmek ve marka aşkının marka sadakati, müşteri memnuniyeti ve marka imajına etkisini akıllı telefon markaları özelinde ortaya koymaktır. Bu etkileri incelemek ve sonuçlara ulaşabilmek için, Balıkesir Üniversitesi Burhaniye Uygulamalı Bilimler Yüksekokulu ve Balıkesir Üniversitesi Burhaniye Meslek Yüksekokulu öğrencileri arasından kolayda örnekleme yöntemi kullanılarak araştırmaya katılan 707 ögrenci üzerinde anket yöntemiyle bir araştırma yapılmıştır. Toplanan veriler üzerinde doğrulayıcı faktör analizi yapılmış; verilerin analizinde yapısal eşitlik modellemesi kullanılmıştır. Araştırma sonucunda marka güveni ve yenilikçiliğinin marka aşkın doğrudan etkilediği bulgusuna ulaşılmıştır. Tüketici ilgilenimi boyutlarından ilgi ve hedonik değer marka aşkını etkilerken, sembolik değerin marka aşkına etkisi tespit edilememiştir. Marka aşkının ise müşteri memnuniyeti, marka imajı ve marka sadakatinin iki boyutu üzerinde etkisi olduğu sonucuna ulaşılmıştır. Araştırma kapsamında bulunan sonuçlara göre işletmelere ve araştırmacılara önerilerde bulunularak çalışma tamamlanmıştır.

$\begin{array}{lcccc}\text { Keywords: } & \text { Brand Love } & \text { Smart Phone Loyalty } & \text { Trust } & \text { Satisfaction } \\ \text { JEL Codes: } & \text { M30 } & \text { M31 } & \end{array}$

\footnotetext{
1 Bu çalışma, Doç. Dr. Volkan Özbek danışmanlığında Öykem Doğan tarafından yürütülen Marka Aşkının Öncülleri ve Sonuçları Üzerine Bir Araştırma isimli yüksek lisans tezi temelinde geliştirilmiştir

2 Doç. Dr., Balıkesir Üniversitesi, vozbek@balikesir.edu.tr,

${ }^{3}$ Doç. Dr., Kocaeli Üniversitesi, fatih.koc@kocaeli.edu.tr,

4 Bilim Uzmanı, Balıkesir Üniversitesi, oykemdogan@gmail.com, 


\section{EXTENDED ABSTRACT}

\section{ANTECEDENTS AND CONSEQUENCES OF BRAND LOVE:}

\section{A RESEARCH ON SMARTPHONE PRODUCTS}

\section{LITERATURE}

After Shimp and Madden adapted love triangle (the eternal triangle) theory to consumer behaviour, Kevin Roberts (1998) brought called as love marks or brand love concept in marketing literature. The transition from being a brand to love mark means the transformation of rational relationship to the emotional relationship between consumers and a brand. The bond between the brand that has been a love mark and consumers is powerful, so much so that faults of these brands such as lack of innovation, bad timing, or unperfect price usually forgiven (Roberts, 2010, p.25). Also, consumers having love feelings about a brand are disposed to pay more for and have higher level repurchase intention to a product they want to own (Thomson et al., 2005, p.88). Lovemark becomes possible by generating a strong emotional bond between a consumer and the brand, and this bond depends on building up loyalty to and creating defensiveness against the brand. Lovemark concept is used for indicating products, services, or assets constituted "loyalty beyond reason" (Pawle and Cooper, 2006, p.38-39). Studies demonstrated that loving a brand cause loyalty. Therefore, marketers attempt to make their consumers feel love for their brands in order to keep pace with their competitors (Kazemi and Borandegi, 2013, p.322).

\subsection{RESEARCH SUBJECT}

In this study, brand love's interactions with its consequences and antecedents, such as brand trust, brand innovativeness and involvement, have been investigated. According to Aydin (2017, p.282), brand trust causes brand love. Similarly, according to Turgut (2014), trust positively affects brand love. When consumers love and trust a brand, they are resistant to negative criticism and information against the brand. On the other part, the innovation concept is the cause of love and romanticism feelings. Brands are making innovation achieve more commitment to the brand because of providing more stimulation in comparison with non-innovative brands (Aydin, 2016, p.131). In addition to this, ensuring consumers feel emotional bond for a brand, use this brand, and spend some money to be able to buy this brand is an essential factor in order to create brand love. Firms should plan strategies to make consumers curious about and take an interest in the brand until the moment of sale while designing, packing, and promoting branded products (Arslan ve Nur, 2018, p.115). Besides, the formation of a feeling of love toward the brand that of interest, and attributed to importance can wait.

Among the factors affected by brand love, customer satisfaction, brand loyalty, and brand image can be counted. Indeed, it is expected that brand love emanated people's satisfaction and loyalty levels are higher than other customers (Aşkın and İpek, 2016, p.81). It is conceivable that consumer who has an emotional relationship with a brand will also have high-level satisfaction from products of this brand. Also, consumers establishing strong connections with a brand could give advice to their friends and environment to buy the brand they are using (Onurlubaş and Altunışı, 2019, p.131). On the other hand, based on brand image literature and the idea that consumers may anthropomorphize brands, it is asserted that emotional levels of consumers affect brand image (İsmail and Spinelli, 2012, p.389).

\subsection{RESEARCH PURPOSE AND IMPORTANCE}

Purposes of this study are determining effects of consumers' trust in the brand, belief in brand's innovativeness, and involvement levels on brand love and presenting effects of brand love on loyalty, customer satisfaction, and brand image, specific to smartphone brands.

\subsection{CONTRIBUTION OF THE ARTICLE TO THE LITERATURE}

To reveal the structure of brand love, it is expected that examining antecedents and consequences of this concept will contribute to the literature. 


\section{DESIGN AND METHOD}

\subsection{RESEARCH TYPE}

In this research, the data was gathered with the survey method and analyzed by using quantitative research methods.

\subsection{RESEARCH PROBLEMS}

The main research problem of this study is determining whether some variables thought as antecedents and consequences of brand love have expected relationships.

\subsection{DATA COLLECTION METHOD}

The population of the study is composed of university students. In the study, data was gathered by conducting questionnaires to students determined with convenience sampling. Seven hundred seven valid surveys were included in analyses.

\subsection{QUANTITATIVE ANALYSIS}

Primarily, validity and reliability analyses, confirmatory factor analysis, and correlation analysis were used in the analysis of data. In order to test the research model, Structural Equation Modeling (SEM) was used.

\subsection{RESEARCH HYPOTHESES}

$\mathbf{H}_{1}$ : Consumer trust in smartphone brands has a positive effect on brand love.

$\mathbf{H}_{2}$ : Innovations made by smartphone brands have positive effects on brand love.

$\mathbf{H}_{3}$ : Relevance dimension of consumer involvement toward smartphone brands has a positive effect on brand love.

$\mathbf{H}_{4}$ : Hedonic value dimension of consumer involvement toward smartphone brands has a positive effect on brand love.

$\mathbf{H}_{5}$ : Symbolic value dimension of consumer involvement toward smartphone brands has a positive effect on brand love.

$\mathbf{H}_{6}$ : Brand love felt for smartphone brands has a positive effect on customer satisfaction.

$\mathbf{H}_{7}$ : Brand love felt for smartphone brands has a positive effect on recommendation dimension of loyalty.

$\mathbf{H}_{8}$ : Brand love felt for smartphone brands has a positive effect on repurchase dimension of loyalty.

$\mathbf{H}_{9}$ : Brand love felt for smartphone brands has a positive effect on brand image.

\section{FINDINGS AND DISCUSSION}

\subsection{FINDINGS AS A RESULT OF ANALYSIS}

Results of reliability and validity analyses show that research scales are reliable and valid. As a result of testing research model via Structural Equation Modeling, it is seen that the structural model demonstrated acceptable goodness of fit. Additionally, results of hypotheses tests revealed that all hypotheses had been supported, except H5.

\subsection{HYPOTHESIS TEST RESULTS}

Hypotheses asserting positive effects of brand trust (H1), brand innovativeness (H2), and relevance $(\mathrm{H} 3)$ and hedonic value $(\mathrm{H} 4)$ dimensions of consumer involvement on brand love have been supported. On the contrary, the H5 hypothesis suggesting a positive effect of symbolic value dimension of involvement on brand love has not been supported. However, it is confirmed that repurchase (H6) and recommendation (H7) dimensions of brand loyalty have been affected by brand love. Moreover, H8 and H9 hypotheses proposed positive effects of brand love on customer satisfaction and brand image have been supported. 


\subsection{DISCUSSING THE FINDINGS WITH THE LITERATURE}

According to the results of the research, trust affects brand love directly. This result demonstrates that consumers first require trust in a brand in order to establish a bond with this brand. Overlapping with the results of this research, Kalyoncuoğlu (2017) has determined that there is a positive and significant relationship between trust and love which customers have to the brand, and Onurlubaş and Altunışı (2019); Albert and Merunka (2013); Turgut (2014) have determined that brand trust has a significant effect on brand love. According to the findings of the research, the more brands are innovational, the higher they have a chance to create a consumer group who are in love with them. Overlapping with the results of this research, Aydın (2016) and Özbek, Kutbay, Doğan and Külahlı (2017) have determined that brand innovation has a positive and significant relationship with brand love. In this context, it can be stated that research findings are coherent with the literature. Research results demonstrate the level of brand love increases in case that consumers regard smartphone as an essential product, have a particular interest in the product and enjoy the product. Supportively, Hegner, Fenko, and Travest (2017) have determined that high involvement level cause brand love. Besides, Ranjbarian, Kazemi and Borandegi (2013) have determined that consumers' involvement in the product has an effect on brand love in their study on smartphone users. In parallel with the results of this research, Carroll and Ahuvia (2006) have confirmed that hedonic products affect brand love and Huber, Meyer and Schmid (2015) have determined that hedonic value has essential effects on brand love.

Results revealed in the research indicate that brand love affects recommendation and repurchase dimensions of loyalty. Overlapping with the results of this research, Arslan and Nur (2018) have determined there is a positive and significant relationship between brand love and repurchase intention in a study they carried out in ready-made clothing sector and Fetscherin (2014); Sarkar, Ponnam and Murthy (2012); Aydın (2016) have determined that brand love has a positive and significant effect on repurchase in their studies. Besides, Carroll and Ahuvia (2006); Albert, Merunka and Valette-Florence (2008); Batra et al. (2012); Albert and Merunka (2013); Fetscherin (2014) have determined in their studies that brand love affects word of mouth marketing and thereby recommendation positively. According to the results achieved in the research, brand love affects brand image positively. Based on this result, it can be stated that as the level of consumers' brand love increases, their outlook on the brand's image would increase positively as well. Overlapping with the results of this research, Kang (2015), in the study carried out on smartphones in India, has determined that brand love has a positive effect on brand image.

\section{CONCLUSION, RECOMMENDATION AND LIMITATIONS}

One of the most critical factors to create a brand love is brand trust. Firms which are striving to create a brand love must first give trust to their customers. Trust has tremendous importance in the smartphone sector just as in the others. Customers want to trust in the product, brand and company before, during and after buying the product. In the smartphone sector, the customer may be given confidence with the warranty after the sale of the product. By providing these, consumers are more likely to have an emotional bond with the brand.

Consumers prefer those bringing innovation, improving themselves, and making progress rather than ordinary ones. According to the results of researches, innovative brands are loved more in comparison to non-innovative ones. It is very often to introduce a new type of cell phone today, and innovation race immensely increased (transferring charge from a smartphone to other, artificial intelligence, face recognition etc.). In the meanwhile, companies having a desire to create a brand love must give more importance to R\&D activities.

In the study, the result that relevance and hedonic value dimensions of consumer involvement concept affect brand love was determined. According to this result, companies having a desire to create a brand love must find out what attracts consumers' relevance, what kind of products make them happy and what gives them delight by conducting market researches. Companies that present products attracting customers' relevance and giving them delight may create more brand lovers in comparison to others.

Companies want their customers to re-choose their brands and recommend that people around them use the same brand. Because of these reasons, companies that do not desire to lose 
current customers must give enough importance to brand loyalty, and they must do researches to develop it. Companies that giving critical importance to brand love and that striving to create consumers who love their brand are in an advantageous position about creating customer loyalty. Similarly, brands must please the customers if they want a long-life span in the marketing world since brand love has a significant position to create satisfaction. On the other hand, companies desire to see themselves in a good position in consumers' eyes. A strong brand image must be created in customers' eyes to have a good position. Creating brand love is likely useful for a positive image.

Within the scope of the study, brand trust, brand innovation and consumer involvement (relevance, hedonic value and symbolic value) which are antecedents of brand love are researched and analyzed. In future studies, using different parameters which may be antecedents of brand love will be useful to reach different results. In the process of research, loyalty (repurchasing and recommending), customer satisfaction and brand image as consequences of brand love were searched. Different studies may be carried out about this subject, and literature may be contributed by using different parameters which are affected by brand love. This study was able to be carried out on undergraduates and only with undergraduates of Burhaniye Applied Sciences School and Burhaniye Vocational School affiliated to Balıkesir University due to limited time and cost. The validity of the results may be improved by testing the research model on different populations. Within the scope of the study, brand love, its antecedents, and consequences have been evaluated specific to smartphone products. Same antecedents and results may be studied in specific to different sectors and products. 


\section{GİRIŞ}

Rekabetin her geçen gün arttığı dünyada, firmalar güçlü alternatifler arasında tüketicilerin aklında ilk sırada yer almak ve sonraki alışverişlerinde de aynı sırada kalmak isterler. Bunu başarabilmek için tüketicilerin gözünde sıradan markalar olmaktan öteye geçip birer aşk markası olmayı hedeflerler. Zira firmalar, sadakatin gelişmesinde marka ile müşteri arasında aşk duygusunun oluşmasının önemini kavramışlardır (Roberts, 2005). Ancak bir markanın, aşk markasına dönüşmesi çok da kolay değildir. Bunu başarabilmek için, öncelikle marka aşkının neyi ifade ettiği, bu kavramın hangi faktörlerden etkilendiği ve hangi unsurları etkilediği iyice anlaşılmalıdır.

Araştırmacılar yıllardır tüketicilerin markalara karşı gösterdikleri "sevmesevmeme" şeklindeki tutumlarını araştırmışlardır. Ancak, son birkaç yılda tüketicilerin markalar için duydukları aşk konusu hem işletmeler hem de akademisyenler arasında oldukça dikkat çekici bir konu haline gelmiştir (Batra ve diğerleri, 2012, s.1). Yıllardır Starbucks Coffee, Harley-Davidson ve Manolo Blahnik gibi şirketler müşterileriyle derinlemesine köklü duygusal bağlar kurmayı ve bunu sürdürmeyi başaran markalara örnek olmuştur. Günümüzde ise tüketiciler markalarıyla olan aşk ilişkisini hevesle başkalarına anlatmaktadır. Pazarlamacılar arasında da sevilen markalar fikri hız kazanmış ve marka aşkı oluşturmak için duygusal açıdan zengin reklam mesajları kullanılmaya başlanmıştır. Bununla birlikte, çeşitli araştırmalarda tüketiciler ile markalar arasında güçlü bir bağ oluşturmak için aşk duygusunun önemli bir rol oynadığına dair sonuçlar ortaya konmuştur (Bauer ve diğerleri, 2009, s.252). Bu çalışmaların bir kısmı marka aşkının öncülleri (Carroll ve Ahuvia, 2006; Bergkvist ve Bech-Larsen, 2010; Albert ve Merunka, 2013) ve sonuçları (Thomson ve diğerleri, 2005; Carroll ve Ahuvia, 2006; Albert, Merunka ve Valette-Florence, 2008; Batra ve diğerleri, 2012) üzerine gerçekleşmiş ve bu çalışmalarda güven, itibar, memnuniyet, ilgilenim ve sadakat gibi tüketici duyguları ile marka aşkı arasındaki ilişkiler irdelenmiştir.

Genç tüketicilerin yoğun bir şekilde kullandığı ürünlerden birisi akıllı telefonlardır. Yenilikçilik açısından düşünüldüğünde, akıllı telefonlar pazarda önemli bir yer tutmaktadır (Cecere ve diğerleri, 2015, s. 162). Ayrıca, genç 
tüketicilerin akıllı telefon markalarına yönelik bağlılık düzeyi oldukça yüksektir (Akın, 2017, s.104; Filieri ve Lin, 2017, s.139). Bu açıdan bakıldı̆̆ında, yenilikçiliğin marka aşkı oluşumunda etkili olacağı düşünülebilir.

İkili ilişkilerde samimiyetin artması için elzem olan güven kavramının, kişi ile marka arasındaki ilişkinin gelişiminde de etkili olması beklenebilir. Güvenin, özellikle ilişki gelişiminin ilk döneminde, üst düzey ilişkiler geliştirmenin ana unsuru olduğu bilinmektedir (Liang ve Wang, 2008, s.68). İyi ilişkiler geliştirmeden marka aşkı oluşturabilmek ise neredeyse imkansızdır. Bu nedenle, güven kavramı marka aşkı oluşturmada dikkate alınması gereken bir faktördür.

İlgilenim, kişinin ihtiyaçları, ilgi alanları ve kişisel değer yargılarına göre şekillenen, bir nesneye karşı duyduğu ilgi olarak tanımlanmaktadır (Zaichkowsky, 1985, s.342). Tüketicilerin kendi markalarına karşı aşk duygusu beslemesini arzu eden firmaların, ürüne ve markaya yönelik ilgiyi geliştirmesinin ve bu ilgilenimden yararlanarak markasını bir aşk markasına dönüştürmesinin daha kolay olabileceğini düşünmek mümkündür.

Firmaların hedefledikleri aşk markalarını oluşturabilmeleri halinde, müşterilerini daha kolay memnun edebilecekleri ve onları kendilerine sadık hale getirebilecekleri söylenebilir (Carroll ve Ahuvia, 2006). Bu noktada müşteri memnuniyeti ve marka sadakati kavramları marka aşkı tarafından etkilenebilecek birer unsur olarak düşünülebilir. Nitekim marka aşkı oluşan kişilerin memnuniyet ve sadakat düzeylerinin diğer müşterilerden daha yüksek olması beklenmektedir (Aşkın ve İpek, 2016, s.81). Ayrıca, belirli bir markaya aşk duygusuyla bağlı bir müşterinin, bu markanın bağlı olduğu işletmeye de olumlu duygular beslemesi olağandır. Bu nedenle, marka aşkı oluşturulduğunda, firmanın müşteri gözündeki imajının yükseleceği düşünülebilir.

Yukarıda beklenti olarak ifade edilen ilişkiler dikkate alındığında, bu araştırmanın amacı marka güveni, marka yenilikçiliği ve tüketici ilgilenimi değişkenlerinin marka aşkı üzerindeki etkisini, marka aşkının ise müşteri memnuniyeti, marka sadakati ve marka imajı üzerindeki olası etkilerini bir model ile ortaya koymaktır. Literatürde bu ilişkilerin ayrı ayrı değerlendirildiği çalışmalar 
bulunmakla birlikte, bu araştırmada kullanılan değişkenlerin ve olası etkileşimlerin bir modelle incelendiği başka bir çalışmaya rastlanmamıştır. Ayrıca bu değişkenler arasındaki etkileşimlerin akıllı telefon ürünü özelinde incelenmesinin literatüre katkı sunacağ1 düşünülmektedir.

\section{KURAMSAL ÇERÇEVE VE İLGİLI ALANYAZIN}

\subsection{Marka Aşkı Kavramı}

Sternberg (1986) çalışmasında kişiler arasındaki aşkı Aşk Üçgeni Teorisi adı altında boyutlara ayırarak incelemiştir. Bu boyutlar; samimiyet, tutku ve karar olarak adlandırılmıştır. Samimiyet bileşeni; ilişkilerde yakınlık ve bağlılık duygularını içermektedir. Kısaca, kişilerin birbirlerine yakın hissetme hali olarak ifade edilebilir. Tutku bileşeni sevgi dolu bir ilişkide tutku deneyimine yol açan romantizm ve fiziksel çekim gibi motivasyon kaynaklarını ve diğer uyarılma türlerini içerir. Karar bileşeni ise kısa vadede birinin başkasını sevme kararına ve uzun vadede bu sevgiyi sürdürme taahhüdüne işaret etmektedir (s. 119).

Aşk Üçgeni Teorisi'nden hareketle Shimp ve Madden (1988) insan ilişkileri ile tüketici-nesne ilişkileri arasında çeşitli kıyaslamalar yaparak bu teoriyi pazarlama alanına adapte etmiştir. Aşk Üçgeni Teorisi'ndeki yakınlık, tutku ve karar boyutları Shimp ve Madden (1988) tarafından beğenme, özlem ve karar/bağlılık şeklinde adlandırılmıştır. Beğenme bileşeni; bağlılık ve düşkünlük gibi duyguları ifade etmektedir. Gerçekten de tüketiciler yaşamları boyunca tüketim nesnelerine karşı bu gibi duygular beslemektedirler. Örneğin bir çocuk, değer verdiği bir battaniyeden veya bir bebekten ayrılamamaktadır. Özlem bileşeni; tüketicinin bir nesneye sahip olmaya yönelik ciddi veya güçlü bir arzu halidir. Karar/bağlılık bileşeni ise bir ürünün özelliklerinin tüketicinin aradığı şey ile uyumlu halde olması sebebiyle kısa vadede tüketiciler tarafından ürünün sevilmesine, uzun vadede ise sadakate sebep olabilen bir bileşendir (s. 164-165).

Shimp ve Madden'in Aşk Üçgeni Teorisi'ni tüketici davranışlarına uyarlamasının ardından, Kevin Roberts aşk markası (lovemarks) veya marka aşkı olarak adlandırılan kavramı pazarlama literatürüne kazandırmıştır. Aşkı, beğenmenin ve hayran olmanın ötesinde bir durum olarak tanımlayan Roberts, bir markaya karşı aşk oluşturmak için birçok duygunun tatmin edilmesi gerektiğini 
ifade etmektedir (Roberts, 2005, s.36-39). Marka aşk1 üzerine yapılan ilk çalışmalardan birine imza atan Carroll ve Ahuvia (2006) ise bu kavramı "memnun bir tüketicinin belirli bir markaya karşı beslediği tutkulu duygusal bağlılık derecesi" olarak tanımlamaktadır.

Bir marka olmaktan aşk markası olmaya geçiş tüketici ile marka arasındaki rasyonel ilişkinin duygusal bir ilişkiye dönüşmesi anlamına gelmektedir. Aşk markası haline gelen bir markanın tüketici ile arasındaki bağ çok güçlüdür. Öyle ki bu markaların yenilik eksikliği, iyi olmayan zamanlama veya mükemmel olmayan fiyat gibi hatalarının genellikle bağışlandığı görülmektedir (Roberts, 2010, s.25). Ayrıca, markalarına karşı aşk duygusu besleyen tüketiciler, sahip olmak istedikleri ürüne karşı daha fazla ödemeye istekli olmakta ve daha yüksek düzeyde bir yeniden satın alma niyetine sahip olmaktadır (Thomson ve diğerleri, 2005, s.88).

Marka aşkı, tüketici ile marka arasında güçlü duygusal bağlar oluşturmakla mümkündür. Bu bağ ise sadakati oluşturmakta ve o markaya karşı savunuculuk yaratmaktadır. Nitekim marka aşkı kavramı "aklın ötesinde bir sadakat" oluşturan mal, hizmet ya da varlıklar için kullanılmaktadır (Pawle ve Cooper, 2006, s.38-39). Yapılan çalışmalar bir markayı sevmenin sadakate yol açabileceğini göstermiştir. Bu nedenle pazarlamacılar, rakiplerine ayak uydurabilmek için müşterilerinin markalarına karşı aşk duymalarını sağlamaya çalışmaktadır (Kazemi ve Borandegi, 2013, s.322).

\subsection{Marka Aşkının Öncülleri}

\subsubsection{Marka Güveni}

İnsan ilişkilerinin temelini oluşturan güven, ticari ilişkilerin ve bu yönde yapılan pazarlama çabalarının da temelini oluşturmaktadır. Bu nedenle pazarlama çabalarının çoğu güven temeli üzerine kurulmuştur. Reklamlarda doğrudan veya dolaylı olarak sembollerle güven mesajları verilmeye çalışılmaktadır. Böylelikle tüketicilerin güvendikleri markaları satın almaları ve güven yoluyla bağlılık yaratmak amaçlanmaktadır (Erdil ve Uzun, 2010, s.189-190).

Markayı kişileştirilmiş bir varlık olarak düşünen müşteri, bu varlıktan güvenli ve uzun vadeli reaksiyonlar beklemektedir. Bu beklentilerin karşılanması halinde 
müşterinin mutluluk duyacağı varsayılmaktadır. Ayrıca güven kavramı, tüketicilerin olumlu bir ilişki oluşturmak amacıyla geçirmeleri gereken bir süreçtir (Swaen ve Chumpitaz, 2008, s.13). Diğger bir tanıma göre güven, müşterilerle uzun dönemli ilişkiler oluşturma ve bu ilişkilerin sürdürülmesinde temel bir faktör olarak kabul edilmektedir (Sharma ve Patterson, 2000, s.471). Marka güveni, ortalama bir tüketicinin, markanın belirtilen işlevini yerine getirme yeteneğine inanmasına istekli olmasıdır (Chaudhuri ve Holbrook, 2001, s.82). Ayrıca, tüketicinin markaya dair pozitif beklentilerini ve markaya karşı inançlarını ifade etmektedir (Luk ve Yip, 2008, s.453). Marka güveni, tüketicinin bir markanın beklentilerini karşılayacağına yönelik duyduğu güvence hissidir (Ballester ve Aleman, 2001, s.1242).

Marka güveni yaratmak isteyen bir işletme, müşterilerin şüphelerini gidererek marka ile müşteri arasındaki ilişkiyi güçlendirebilecektir (Erdil ve Uzun, 2010, s.83). Marka güveninin müşteri memnuniyeti ve marka bağlılığı arasında bir köprü rolü oynadığ1 söylenebilmekle beraber, bu güven neticesinde oluşan memnun müşterilerin marka imajına da olumlu yönde etki edebileceği öngörülmektedir (Doğan ve Özkara, 2013, s.8). Bir müşterinin belirli bir markaya güven duyması, güven duyduğu markadan uzun dönemde sağlayacağı faydalar nedeniyle rakip markaların kısa vadeli alternatiflerine yönelmesini engelleyecek ve müşteri güven duyduğu firmanın fırsatçı davranışlar sergilemeyeceği yönündeki inancından dolayı rakip markalara daha temkinli yaklaşabilecektir (Morgan ve Hunt, 1994, s.22).

Aydın (2017, s.282)'a göre marka güveni, marka aşk1 oluşturmada önemli bir role sahiptir. Benzer şekilde Turgut (2014)’a göre marka güveni, marka aşkını olumlu yönde etkileyebilmektedir. Tüketiciler bir markayı sevdiklerinde ve güvendiklerinde markaya yöneltilen olumsuz haberlere ve bilgilere karşı dirençli olurlar. Literatürde yer alan bu bulgulardan hareketle aşağıdaki hipotez kurgulanmıştır.

H1: Akıllı telefon markalarna karşı duyulan marka güveninin, marka aşkı üzerinde pozitif bir etkisi vardır.

\subsubsection{Marka Yenilikçiliği (İnovasyon)}

Değişen ve gelişen dünyada işletmeler için yenilik en önemli rekabet ve karlılık araçlarından biri haline dönüşmüştür (Eskiler ve diğerleri, 2011, s.32). 2000'li 
yıllardan itibaren iş dünyasında sıkça konuşulmaya başlanan yenilik kavramı, rekabet dünyasında ayakta kalabilmenin bir şartı olarak görülmekte ve bu kavram üzerine birçok çalışma yapılmasına neden olmaktadır. Bu kavram, yeniliğin kendisinden çok sonucunu farklılaştırma ve değiştirmeye bağlı ekonomik ve toplumsal bir süreci ifade etmektedir (Elçi ve diğerleri, 2008, s.25). Yenilik kavramı, verimliliği, etkinliği veya rekabet avantajını arttırma amacıyla yeni bir mal, hizmet veya sürecin oluşturulması, geliştirilmesi ve uygulanması anlamına gelmektedir (Nemati ve diğerleri, 2010, s.299).

Günümüzde işletmeler uzun süre ayakta kalabilmek için zamanın ruhunu yakalamak durumundadırlar. Zamanın ruhu; yapılmayanı yapmak, denenmemişi denemek, buluşçu ve hızlı olmak demektir. İnovasyon iş dünyasında artık bir zorunluluk haline gelmiştir. İşletmeler istese de istemese de inovasyon onların kurumsal kimliğinin bir parçası olmak zorundadır. Çünkü bugünün dünyası, adına 'inovasyon ekonomisi' verilen yenilikçi buluş fırtınasıyla sallanmaktadır (Altun, 2007, s.12).

Son yıllarda rekabetin üst seviyelere ulaştı̆̆ı akıllı telefon sektöründe, yapılan araştırmalar akıllı telefon sektörünün yeni ürün tanıtımı ve çeşitli tasarımlar açısından büyük ölçüde yenilikçi olduğunu göstermektedir. Bu sadece cihazların teknik özelliklerinde meydana gelen değişikliklerle değil, aynı zamanda işletim sistemindeki değişikliklerle de ilgilidir. Öte yandan, pazarlama ve teknolojik olmayan yenilikler de ürünlere yeni özellikler eklenmesine ve ürünlerin rakiplerin sunduklarından farklı hale gelmesine yardımcı olmaktadır (Cecere ve diğerleri, 2015, s.174).

Markanın ürün veya hizmetlerinde meydana gelen olumlu değişiklik veya farklılıklar marka yeniliği olarak değerlendirilmektedir. Yenilik kavramı aşk ve romantizm duygularının nedenidir. Yenilik yapan markalar, kendini yenilemeyen markalara göre daha çok uyarılma sağladıklarından dolayı markaya daha fazla bağlanmaya neden olmaktadır (Aydın, 2016, s.131). Literatürde yer alan bu bulgulardan hareketle aşağıdaki hipotez kurgulanmıştır. 
$\mathbf{H}_{2}$ : Akıllı telefon markalarının yapmış oldukları marka yenilikçiliğinin, marka aşkı üzerinde pozitif bir etkisi vardır.

\subsubsection{Tüketici İlgilenimi}

İlgilenim, tüketici davranışlarının anlaşılabilmesi ve açıklanabilmesi amacıyla uzun zamandır faydalanılan önemli bir konudur (Çakır, 2007, s.163). Sosyal psikoloji alanında yapılanan ilgilenim kavramı, özelikle 1965 ve 1980 yılları arasında sosyal bilimlerde pazarlama, tüketici davranışları ve reklamcılık alanlarında da farklı açılardan incelenmiş ve tartışılmıştır. Bu sebeple ilgilenim kavramıyla ilgili her bilim alanında farklı tanımlar ve sınıflandırılmalar ortaya çıkmıştır (Ulusu, 2016, s.570).

İlk olarak 1947 yılında Sherif ve Cantril tarafından geliştirilen ilgilenim kavramı (Leong ve diğerleri, 2017, s.75), Krugman'ın 1965 yılında televizyon reklamlarının öğrenilme şekillerine yönelik yapmış olduğu çalışmasından sonra pazarlama alanında odak noktası haline gelmiştir (Çakır, 2007, s.163). İlgilenim kavramını pazarlama dünyasına kazandıran Krugman (1965) bu kavramı, televizyon izleyicisinin bir dakika içinde uyarıcı ile kendi hayatı arasında bilinçli bir şekilde kurduğu ilişki, köprü, bağlantı veya kişisel referans sayısı olarak tanımlamıştır (Kandemir ve diğerleri, 2013, s.23). Televizyon reklamlarının düşük ilgilenime sahip olduğunu ortaya koyan Krugman, bu sonuçla sadece reklamcılık alanında değil aynı zamanda tüketici davranışı teorisi ile ilgili pazarlama araştırmalarında da büyük bir etki yaratmıştır. Bu çalışmadan sonra ilgilenim konusu tüketici davranışı araştırmalarında ana akımın bir parçası haline gelmiştir (Lin ve Chen, 2006, s.250).

Tüketicilerin içinde bulundukları belirsizlik durumuna karşı verdikleri bilişsel bir tepki olan ilgilenim (Koç, 2015, s.363-264); mal, hizmet ve reklam gibi uyaranlara karşı hissettiği kişisel düzeyde önem duygusu ve ilgi düzeyidir (Odabaşı ve Barış, 2002, s.342). Traylor (1981), ilgilenimi bir tüketicinin belirli bir ürünü anlaması veya tanıması olarak ifade etmiş ve tüketicinin ürün değerlendirmesinin derecesine göre düşük veya yüksek ilgilenim düzeyinin gerçekleşeceğini belirtmiştir (Traylor, 1981; Akt. Lin ve Chen, 2006, s.250).

Tüketiciler her şeye, aynı önemi vermemekte, aynı şekilde yoğunlaşmamakta ve her şeyi kendileri ile alakalı görmemektedirler. Bu açıdan ilgilenim, tüketicilerin 
olayları, objeleri ya da ürünleri algılarken onlara ne ölçüde önem yüklediğinin ve bu olay, obje veya ürünleri kendileriyle ne derece ilişkili bulduklarının göstergesidir. Ayrıca, bir ürün kategorisi, bir marka, bir satın alma koşulu, pazarlama ya da pazarlama iletişimi mesajına yönelik olarak gerçekleşebilen tüketici ilgilenimi, pazarlamacılara kendi ürünlerine olan ilgilenim derecesini arttırmak suretiyle satış yapmalarına yardımcı olmaktadır. Çünkü düşük seviyede ilgilenime sahip olan tüketiciler pazarlama iletişimi bilgilerini unutma eğiliminde olmakta iken yüksek derecede ilgilenim düzeyine sahip olan tüketiciler pazarlama iletişimi mesajlarına karşı daha duyarlı ve bu mesajlarda çıkarım yapma konusunda daha istekli olmaktadır (Koç, 2015, s.264-265). Tüketicilerin bir ürüne yönelik olarak tüketimleri ile ilgi ve bilgi düzeyleri doğru orantılı olarak gerçekleşmekte ve buna ek olarak bir ürün hakkında bilgili olduğunu düşünen ve o ürüne yönelik ilgilenimi yüksek olan tüketiciler, çevrelerindeki kişileri satın alma konusunda etkilemeye çalışmaktadırlar. Bu sebeple, tüketicilerin ilgilenim düzeyinin yüksek olması pazarlama uygulamaları açısından oldukça önemli bir konudur (Ozansoy, 2010, s.151).

İlgilenim kavramı çok boyutlu bir yapıya sahiptir. Kapferer ve Laurent (1985, s.50) bu boyutları algılanan önem/ilgi, hedonik değer, sembolik değer, risk önemi ve hata olasılığı olarak sıralamıştır (Özbek ve Külahlı, 2016, s.138). Bu çalışma kapsamında algılanan önem/ilgi, hedonik değer ve sembolik değer boyutlarının marka aşkı üzerinde etkili olabileceği düşünülmektedir. Zira bu boyutlar ürüne ilişkin olumlu algılardır ve marka aşkı gibi olumlu bir duyguyu etkilemesi beklenebilir. Öte yandan, ilgilenimin risk önemi ve hata olasılığ1 boyutları ürünü satın alma riskinin ne kadar önemli olduğunu ve ürünü satın almakla hata yapmış olma olasılığının ne kadar yüksek olduğunu ortaya koyan boyutlardır. Dolayısıyla bu boyutlardaki tüketici algılarındaki artışın ya da azalışın marka aşkı üzerinde etkili olabileceği düşünülmemektedir. Ayrıca bu etkinin tespit edildiği ya da incelendiği herhangi bir araştırmaya literatür araştırması sürecinde rastlanmaması da bu boyutların araştırmaya dahil edilmemesinin diğer bir nedenidir.

Kapferer ve Laurent (1985, s.50) algılanan önem/ilgi boyutunu tüketicinin belli bir ürün kategorisine karşı kişisel ilgisi, ürünün kişisel anlamı ya da önemi; hedonik 
değer boyutunu ürünün hazcı değeri, haz ve mutluluk sağlama yeteneği; sembolik değer boyutunu ise ürünün bireyi ifade etme yeteneği şeklinde tanımlamaktadır.

Tüketicilerin bir marka için duygusal bağ hissetmeleri, o markayı kullanmaları ve o markayı satın alabilmek adına bir miktar harcama yapmalarını sağlamak marka aşkının oluşabilmesi için önemli bir unsurdur. Firmalar, markaya ait ürünleri tasarlarken, ambalajlarken, tanıtımını yaparken, satış anına kadar tüketicilerin o markaya karşı merak duymalarını ve ilgi göstermelerini sağlayan stratejiler planlamalıdırlar (Arslan ve Nur, 2018, s.115). Ayrıca ilgi duyulan ve önem atfedilen bir ürüne karşı aşk duygusunun oluşması beklenebilir. Bu doğrultuda aşağıdaki hipotez test edilmiştir.

H3: Akıllı telefonlara yönelik tüketici ilgileniminin ilgi boyutunun, marka aşkı üzerinde pozitif bir etkisi vardır.

Carroll ve Ahuvia (2006, s.86) müşterilerin ürünleri kullanmadan önce ve sonra göstermiş oldukları duygusal tepkilerden hareketle eğlenme ve haz almaya dayalı kullanılan hedonik ürünlere yönelik marka aşkının, hedonik olmayan ürünlerdekinden çok daha fazla olduğunu iddia etmektedirler. Aşkın ve İpek (2016, s.81) ise yaptıkları çalışmada tüketim deneyiminden doğan yüksek derecede keyif ve mutluluk hislerinden oluşan tüketici hazzının marka aşkının öncüllerinden biri olduğunu literatüre dayanarak iddia etmektedir. Araştırmalarda ortaya çıkan bulgulardan hareketle aşağıdaki hipotezin bu araştırma özelinde test edilmesinin alanyazına katkı sunacağı düşünülmektedir.

H4: Akıllı telefonlara yönelik tüketici ilgileniminin hedonik değer boyutunun, marka aşkı üzerinde pozitif bir etkisi vardır.

Carroll ve Ahuvia (2006, s.83)'ya göre tüketiciyi yansıtan ürünlerin ve markaların marka aşkı üzerinde pozitif etkisi vardır. Tüketici markanın kendi benliğini (sembolik olarak) yansıttığını düşünüyorsa markaya yönelik bağlılık ve ilişki kalitesinde artış olması beklenecektir. Ayvaz (2017)’a göre firmaların ürünlerinin imajlarını yaratması ve bir yaşam tarzı sunması gibi bireyler de kendilerine satın almayı tercih ettikleri ürünlerle bir kimlik oluşturabilmektedir. Markalar tüketicinin benliğini ifade etmenin yanı sıra sosyal ortamda diğer 
üyelerden farklılaşma aracı olarak da hizmet eder. Tüketiciler, ürünleri ve markaları oluşturdukları imaja göre değerlendirirler. Tüketiciler sık sık kendi benlik imajını geliştirebilecek ve sürdürebilecek ürünleri almayı tercih ederler (Uyar ve Lekesizcan, 2017, s.158). Alanyazında yer alan bu bulgulardan hareketle aşağıdaki hipotez kurgulanmıştır.

H5: Akıllı telefonlara yönelik tüketici ilgileniminin sembolik değer boyutunun, marka aşkı üzerinde pozitif bir etkisi vardır.

\subsection{Marka Aşkının Sonuçları}

\subsubsection{Müşsteri Memnuniyeti}

Müşteri memnuniyeti, tüketicinin bir ürünü satın almaya karar vermesinden itibaren başlayan, mal veya hizmeti araştırıp, kendine uygun olanı bulması, onu satın alması, kullanması sürecinde de devam eden bir kavram olarak pazarlama alanı açısından son derece önemlidir. Memnuniyet, tüketicinin satın aldığı mal veya hizmetten elde ettiği yararlar ile satın alma öncesindeki beklentilerini karşılaştırması sonucunda ulaştığı olumlu veya olumsuz düşüncesi olarak tanımlanmaktadır (Bostan ve diğerleri, 2005, s.187). Satın alma öncesi oluşan beklenti ile satın alma sonrası sağlanan performans birbirine yakınsa memnuniyet gerçekleşir. Satın alma sonrası gerçekleşen performans beklentinin altında kalırsa memnuniyetsizlik oluşur (Usta ve Memiş, 2009, s.89).

Fornell (1992) daha yüksek müşteri memnuniyetinin daha yüksek pazar payıyla sonuçlanacağını, ürünün fiyat esnekliğini azaltacağını, işletme maliyetlerini düşüreceğini ve firma için yeni müşteriler elde etme maliyetlerini azaltacağını belirtmektedir. Ayrıca, memnun müşteri, sadık müşteri olma eğiliminde olduğundan dolayı müşteri memnuniyetinin firma açısından ayrı bir önemi bulunmaktadır (Fornell, 1992, s.7). Kotler (2017)'e göre ileriye dönük bir ölçü olan müşteri memnuniyetinin düzeyi ne kadar yüksekse müşterinin başka firmalara gitme olasılığg da aynı oranda düşük olur.

Tüketicilerin bir markaya duygusal bă̆ hissetmelerinin, satın alma işleminden sonra da olumlu etkiler yaratacağı düşünülmektedir. Marka aşkı oluşan kişilerin memnuniyet ve sadakat düzeylerinin diğer müşterilerden daha yüksek olması 
beklenmektedir (Aşkın ve İpek, 2016, s.81). Kullandı̆̆ı marka ile arasında duygusal bir ilişki bulunan tüketicinin, bu markanın ürettiği ürünlerden memnuniyet düzeyinin de yüksek olacağı düşünülebilir. Bu noktadan hareketle aşağıdaki hipotez kurgulanmıştır.

$H_{6}$ : Akıllı telefon markalarına karşı hissedilen marka aşkının, müşteri memnuniyeti üzerinde pozitif bir etkisi vardir.

\subsubsection{Marka Sadakati}

Küreselleşen dünyada gelişen teknoloji ile beraber artan rekabet, işletmeleri farklı satış ve pazarlama stratejilerine yöneltmiştir. Teknolojinin rakip firmalar tarafından kolayca taklit edilebilmesine karşın, işletme ve müşteriler arasındaki ilişkilerin taklit edilememesi işletmeleri müşteriler ile uzun dönemli ilişkiler kurmaya ve nihayetinde markalarına karşı sadakat oluşturmaya yöneltmiştir (Selvi, 2007, s.3-12).

Sadakat, müşterinin kendisi için başka seçeneklerin de olduğu durumda, belli bir işletmeye, satıcıya veya bir markaya karşı duyduğu, hissettiği, içten (duygusal) bağl1lık ve tesadüfî olmayan alışveriş eğilimi (tutumu), arzusu ve eylemi (sürekli tercih etmesi) olarak ifade edilmiştir. Ayrıca sadakat markaya yönelik olabileceği gibi belli bir işletmeye de olabilmektedir (Bayuk ve Küçük, 2007, s.287). Marka sadakati ise bir markanın fiyat veya ürün özelliklerinde bir değişikliğe gittiğinde müşterinin başka bir markaya geçme ihtimalini yansıtan bir durumdur (Aaker, 1991, s.9)

Yapılan araştırmalarda genellikle sadık müşterilerin işletme ile olan ilişkilerine değer verdikleri, fiyat toleranslarının yüksek olduğu, işletme bilgi edinme sürecini kolaylaştırıp geri bildirimlerde bulundukları, diğer müşterilere kıyasla daha fazla miktarda satın alma davranışı gerçekleştirdikleri, fırsatçı davranışlarda bulunmadıkları ve işletme ile iş birliği içinde oldukları görülmektedir (Selvi, 2007, s.11). Müşteriler belirli bir markaya sadık olduklarında rakip işletmeler her ne yaparsa yapsın müşterisi oldukları markayı değiştirme ihtimalleri oldukça düşüktür. Marka sadakati yüksek düzeyde olduğunda müşteriler daha düşük fiyatlı, daha farklı özellikler sunan ya da etkileyici reklamlar yapan rakip markalara yönelme eğiliminde bulunmamaktadır (Aaker, 2016, s.179). 
Marka ile güçlü bir bağ kuran tüketici, kullandığı markayı satın almaları için arkadaşlarına ve çevresine tavsiyede bulunabilir (Onurlubaş ve Altunışık, 2019, s.131). Bu doğrultuda, bir markaya aşk bağı ile bağlanmış bir tüketicinin, o markayı başkalarına tavsiye etmesi beklenen bir sonuçtur. Ancak bu sonucun akıllı telefon markaları özelinde sınanmasının literatüre katkı sunacağı düşünülmektedir. Bu noktadan hareketle aşağıdaki hipotez kurgulanmıştır.

H7: Akıllı telefon markalarına karşı hissedilen marka aşkının, sadakatin tavsiye etme boyutu üzerinde pozitif bir etkisi vardır.

Markalarına âşık tüketiciler, âşık oldukları markalara daha fazla ücret ödemeye razıdırlar ve o markayı tekrar satın alma niyetleri giderek artmaktadır (Thomson ve diğerleri, 2005, s.88). Yoğun rekabetin olduğu iş dünyasında firmaların ellerindeki müşterileri kaybetmemeleri çok önemlidir. Eğer bir müşteri, bir markayı seviyorsa ve sürekli o markanın ürünlerini satın alıyorsa, o tüketicinin sadakati yüksek demektir. Müşterilerin markalarını sevmeleri, yakınlık hissetmeleri satın alma sıklığını etkilemektedir (Kalyoncuoğlu, 2017, s.390). Bu doğrultuda marka aşkının yeniden satın alma üzerinde etkili olması beklenebilir.

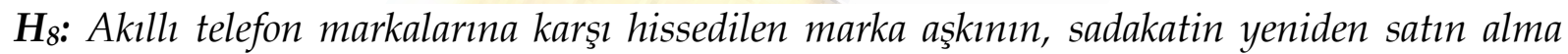
boyutu üzerinde pozitif bir etkisi vardır.

\subsubsection{Marka İmajı}

Tüketiciler bir markayı satın alırken fonksiyon, nitelik ve fayda gibi temel ürün niteliklerinin sağlanmış olmasının yanı sıra markanın bir takım soyut özellikler de taşımasını istemektedirler. Tüketiciler, kendilerine psikolojik fayda ve statü sağlayan, toplumda yer edinmesine aracılık eden, farklılık, zenginlik ve üstünlük gibi göstergeleri olan markalara sahip olmak istemektedirler. Bütün bunlar da marka imajı sağlayarak yaratılmaktadır (Erdil ve Uzun, 2010, s.90).

Farklı kaynaklardan verilere ulaşarak bilgi edinen kişiler, edindikleri bilgileri bir süzgeçten geçirdikten sonra belli bir tutuma yönelmektedirler. Kişilerin inançdeğer-tutum-davranış oluşumu olan algılama sürecinin temel belirleyicilerinden biri yargılardır. Kişilerin dış dünya ile ilgili yargılarının oluşmasında iç dünyalarının da etkisi olduğu için imaj kavramı, içsel ve dişsal faktörlerin etkileşimiyle meydana 
gelmektedir (Gemlik ve Sığrı, 2007, s.268). 1950'lere dayanan kökeniyle pazarlama alanyazınında oldukça geniş bir yer tutan marka imajı kavramı (Padgett ve Allen, 1997, s. 50), tüketicilerin marka ile ilgili deneyimini (Erdil ve Uzun, 2010, s.95) ve marka ile ilgili var olan algılarını yansıtmaktadır (Aaker, 2016, s.200). Bir ürün veya hizmet hakkında tüketicilerin rasyonel ya da duygusal değerlendirmelerinin tümünü içeren (Peltekoğlu, 2007, s.584) ve tüketici davranışları üzerinde etkisi olan marka imajı kavramı, tüketicinin bir marka hakkındaki genel algısını ve hissini ifade etmektedir (Zhang, 2015, s.58). Marka imajı ürünün denenmesi, üretici işletmenin ünü, ürünün ambalajı, marka ismi, kullanılan reklam formatı ve içeriği, reklamın sunulduğu medya gibi çeşitli kaynaklardan sağlanan izlenimler neticesinde oluşmaktadır (Akkaya, 1999, s.101).

Marka imajı alanyazınına ve tüketicilerin markalara insani özellikler atfedebileceği fikrine dayanarak, tüketicilerin sahip olduğu heyecan düzeyinin marka aşkını ve marka imajını etkilediği öne sürülmektedir (Ismail ve Spinelli, 2012, 389). Usta ve Faiz (2019) ise çalışmalarında marka aşkının marka imajı üzerinde etkili olduğunu tespit etmişlerdir. $\mathrm{Bu}$ bulgulardan hareketle aşağıdaki hipotez kurgulanmıştır.

H9: Tüketicilerin akıllı telefon markalarına karşı hissettikleri marka aşkının marka imajı üzerinde pozitif bir etkisi vardır

Yapılan literatür araştırmalarından sonra, hipotezlere uygun olarak hazırlanan araştırma modeli Şekil 5'te görülmektedir. Bu modele göre marka güveni, marka yenilikçiliği ve tüketici ilgileniminin (ilgi, hedonik değer ve sembolik değer) marka aşkına etkisi, marka aşkının da marka sadakati (tavsiye etme ve yeniden satın alma), müşteri memnuniyeti ve marka imajı üzerinde etkisi olduğu düşünülmektedir. 


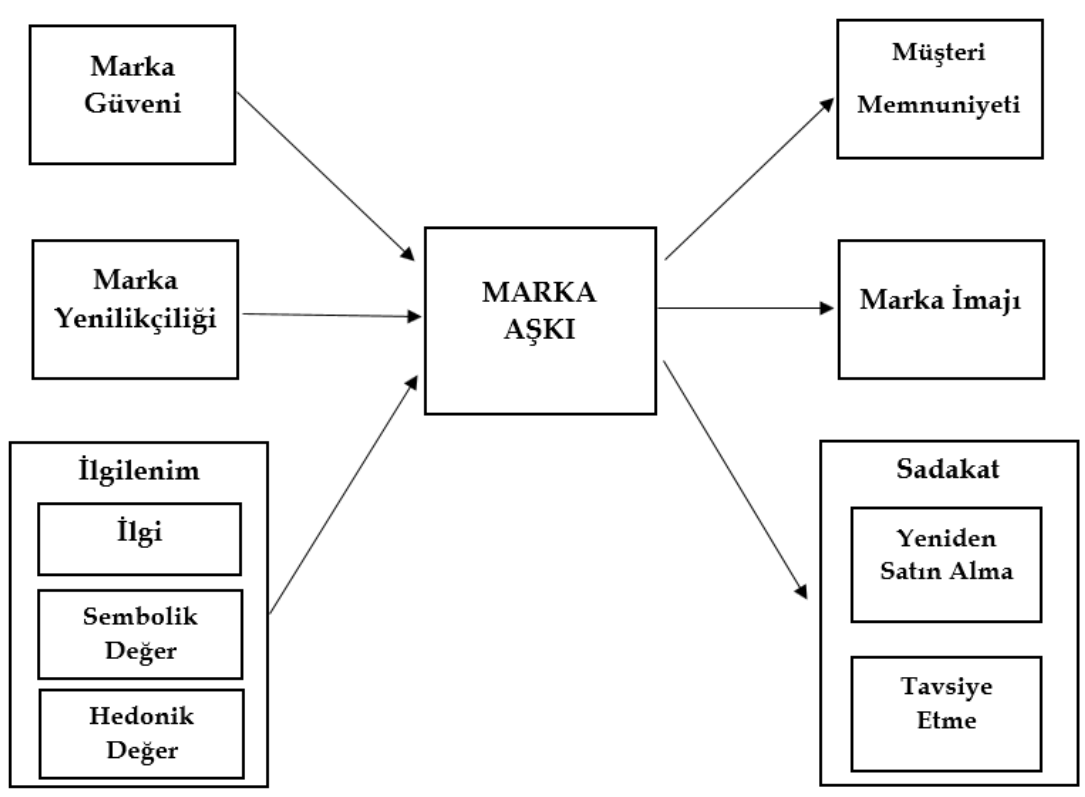

Şekil 1. Araştırmanın Teorik Modeli

\section{YÖNTEM}

\subsection{Araştırmanın Evreni ve Örneklem}

Çalışmanın ana kütlesi Balıkesir Üniversitesi'nin Burhaniye Uygulamalı Bilimler Yüksekokulu ve Burhaniye Meslek Yüksekokulu'nda 2017-2018 Bahar döneminde öğrenim gören öğrencilerden oluşmaktadır. Çalışma yapılırken belirtilen okullarda kayıtlı devamlı öğrenci sayısı yaklaşık olarak 1300'dür. Araştırma, bu okullardan kolayda örnekleme yöntemi ile seçilen 895 öğrenci üzerinde, Şubat-Mart 2018 tarihleri arasında anket yöntemiyle gerçekleştirilmiştir. Doldurulan anketler arasından, katılımcılar tarafından eksik ve yanlış işaretlenenler, soruların hepsinde veya büyük bir çoğunluğunda aynı seçeneğin işaretlendiği tespit edilen ve ters soru yardımı ile okunmadan ya da özensiz bir şekilde cevaplandı̆̆ı anlaşılan anket formları analiz kapsamına dâhil edilmemiştir. $\mathrm{Bu}$ işlemler sonunda, analiz kapsamına dahil edilebilecek 707 anket formu ile analizler gerçekleştirilmiştir. Kullanılabilir durumda olan 707 anketi dolduran öğrencilerin 583'ü Burhaniye Uygulamalı Bilimler Yüksekokulu, 124'ü Burhaniye Meslek Yüksekokulu öğrencisidir.

Araştırmanın üniversite öğrencileri üzerinde yapılmasının nedeni, bu kitlenin akıllı telefon ürünlerini daha aktif kullandığının ve bu ürünlere daha fazla ilgi duyduğunun düşünülmesidir. 


\subsection{Veri Toplama Arac1}

Araştırmada kullanılan veri toplama yöntemi ankettir. Anket yüz yüze uygulanmış ve katılımcılar kolayda örnekleme yöntemi ile seçilmiştir.

Araştırmada kullanılan anket formu, giriş yazısı, demografik özellikleri belirlemeye yönelik sorular ve araştırmanın ana değişkenlerini ölçmeye yönelik sorulardan oluşmaktadır. Anket formunda giriş yazısından sonra, cevaplayıcılara demografik özellikleri, kullandıkları cep telefonu markası, kaç yıldır aynı markanın cep telefonunu kullandıkları, şu an kullanmakta oldukları markanın bugüne kadar kaç modelini kullandıkları ve günde kaç saat cep telefonu ile ilgilendiklerini ölçmeye yönelik sorular sorulmuştur. Demografik özelliklerden sonra ise cevaplayıcılara marka aşkı, marka aşkının öncülleri (güven, yenilik, tüketici ilgilenimi) ve marka aşkının sonuçları (sadakat, memnuniyet ve marka imajı) değişkenlerini ölçmek amacıyla 37 ifade yöneltilmiştir. Bu yanıtların değerlendirilmesi Likert tipi beşli derecelendirme ölçeği kullanılarak yapılmıştır (1-kesinlikle katılmıyorum, 2katılmıyorum, 3- kararsızım, 4- katılıyorum, 5- kesinlikle katılıyorum).

Araştırmada kullanılan ölçeklerin alındığ1 kaynaklar Tablo 1'de sunulmuştur.

Tablo 1. Araştırmada Kullanılan Ölçekler

\begin{tabular}{|c|c|c|}
\hline Ölçek & Kaynak & İfade Sayısı \\
\hline Marka Aşkı & Carroll ve Ahuvia (2006); Aydın (2016) & 5 \\
\hline Marka Yeni & Fang (2008) & 4 \\
\hline Marka Güveni & Lau ve Lee (1999); Aydın (2016) & 4 \\
\hline Tüketici İlgilenimi & Kapferer ve Laurent (1993); Külahlı (2016) & 9 \\
\hline Sadakat & $\begin{array}{l}\text { Zeithaml, Berry ve Parasuraman (1996); Lam, Shankar, } \\
\text { Erramilli ve Murthy (2004); Külahlı (2016) }\end{array}$ & 6 \\
\hline Memnuniyet & Lam, Shankar, Erramilli ve Murthy (2004) & 5 \\
\hline Marka İmaj1 & $\begin{array}{l}\text { Salinas ve Perez (2009); Martin ve Brown (1990); Torlak, } \\
\text { Doğan ve Özkara (2014) }\end{array}$ & 4 \\
\hline
\end{tabular}

\subsection{Verilerin Analizi}

Yapılan anket çalışmasından sonra toplanan verilerin değerlendirilmesinde SPSS 22.0 ve AMOS 18.0 programları kullanılmıştır. Verilerin analizinde öncelikle, geçerlilik ve güvenilirlik analizleri, doğrulayıcı faktör analizi ve korelasyon analizi 
kullanılmıştır. Araştırma modelinin testinde Yapısal Eşitlik Modellemesi (YEM) kullanılmıştır.

\section{ARAŞTIRMANIN BULGULARI}

Bu bölümde öncelikle tanımlayıcı istatistikler, güvenilirlik analizi, korelasyon analizleri ve doğrulayıcı faktör analizi bulguları sunulmuştur. Ardından, araştırma modelini test etmek amacıyla yürütülen yapısal eşitlik modellemesi bulguları gösterilmektedir.

\subsection{Araştırmaya Katılan Cevaplayıcılara İlişkin Tanımlayıcı İstatistikler}

Çalışmanın ana kitlesini oluşturan öğrencilerin \%52,9'u kadın ve \%47,1'i erkektir. Araştırmaya katılan cevaplayıcıların yaş ortalaması 20,83'tür. Katılımcıların \%39,6'sı Apple, \%37,1'i Samsung, \%23,3'ü ise diğer markaların ak1llı cep telefonlarını kullanmaktadır. Cevaplayıcılar arasında şu an kullanmakta oldukları akıllı telefon markasının ürününü/ürünlerini bir yıldır kullananlar 161 (\%22,8) kişi; 2-5 yıldır kullananlar $429(\% 60,7)$ kişi; 6 altı yıl ve daha fazla süredir kullananlar ise 117 $(\% 16,5)$ kişidir.

Araştırmada, cevaplayıcıların cep telefonu olarak kullandıkları markanın bugüne kadar kaç adet telefonunu kullandıkları da sorulmuştur. Sadece bir tane modelini kullanan 311 (\%44,0) kişidir. İki tane modelini kullanan 210 (\%29,7) kişidir. Üç tane modelini kullanan 115 (\%16,3) kişidir. Dört tane ve daha fazla modelini kullanan ise $71(\% 10,0)$ kişi olarak tespit edilmiştir.

Tablo 2'de yer alan sonuçlar incelendiğinde, tüm akıllı telefon markalarının birlikte değerlendirildiği genel kategorisinde marka güveni değişkeninin aritmetik ortalamasının 3,70 olduğu görülmektedir. Bu bulgu, cevaplayıcıların kullandıkları akıllı telefon markasına genel olarak ortalamanın üzerinde bir güven duyduğunu göstermektedir. Marka güveni değişkeni Apple kullanıcıları açısından incelendiğinde, bu markanın kullanıcılarının markaya yönelik güven düzeyinin 4,05 olduğu; Samsung markasının kullanıcılarının bu markaya duyduğu güvenin aritmetik ortalamasının 3,59 olduğu ve diğer markaların kullanıcılarının markalarına güven düzeyinin ortalamasının ise 3,25 olduğu görülmektedir. Marka güveni 
değişkeni markalar özelinde incelendiğinde, en çok güven duyulan markanın Apple olduğu açıkça görülmektedir.

Tablo 2. Araştırmanın Ana Değişkenlerine İlişkin Tanımlayıcı İstatistikler

\begin{tabular}{lcccccccc}
\hline Değişkenler & \multicolumn{2}{c}{ Genel } & \multicolumn{2}{c}{ Apple } & \multicolumn{2}{c}{ Samsung } & \multicolumn{2}{c}{ Diğer Markalar } \\
\cline { 2 - 9 } & Ort. & $\begin{array}{l}\text { Std. } \\
\text { Sap. }\end{array}$ & Ort. & $\begin{array}{l}\text { Std. } \\
\text { Sap. }\end{array}$ & Ort. & $\begin{array}{l}\text { Std. } \\
\text { Sap. }\end{array}$ & Ort. & $\begin{array}{c}\text { Std. } \\
\text { Sap. }\end{array}$ \\
\hline Marka Güveni & 3,70 & 0,85 & 4,05 & 0,78 & 3,59 & 0,82 & 3,25 & 0,79 \\
Marka Yenilikçiliği & 3,73 & 0,89 & 4,18 & 0,73 & 3,63 & 0,80 & 3,11 & 0,85 \\
Tavsiye Etme & 3,60 & 0,94 & 4,00 & 0,78 & 3,55 & 0,85 & 2,99 & 1,01 \\
Y. Satın Alma & 3,51 & 1,09 & 4,11 & 0,86 & 3,42 & 0,94 & 2,63 & 1,05 \\
Marka Aşk1 & 3,45 & 0,87 & 3,84 & 0,76 & 3,39 & 0,77 & 2,89 & 0,85 \\
Memnuniyet & 3,85 & 0,78 & 4,15 & 0,68 & 3,82 & 0,7 & 2,89 & 0,85 \\
Marka İmaj1 & 3,85 & 0,87 & 4,40 & 0,68 & 3,74 & 0,72 & 3,11 & 0,74 \\
İlgi & 3,25 & 1,02 & 3,62 & 0,94 & 3,24 & 0,92 & 2,65 & 1,02 \\
Hedonik Değer & 3,44 & 0,98 & 3,83 & 0,83 & 3,37 & 0,96 & 2,88 & 0,95 \\
Sembolik Değer & 2,61 & 1,07 & 2,63 & 1,16 & 2,67 & 1,03 & 2,47 & 0,95 \\
\hline
\end{tabular}

Marka yenilikçiliği ölçeğinin tüm markalar için genel ortalaması 3,73'tür. Bu sonuç kullanıcıların markalarını yenilikçi bulduklarını göstermektedir. Ayrıca bu ortalama marka aşkının öncülleri arasında en yüksek ortalamadır. Apple kullanıcıları 4,18 gibi yüksek bir aritmetik ortalama ile beraber markalarının yenilik yapma konusunda çok iyi olduğunu düşünmektedirler. Samsung kullanıcılarının aritmetik ortalaması 3,63'tür ve markalarının yenilik konusunda iyi olduklarını düşünmektedirler. Diğer markaların yenilikçilik algısı ise 3,11 ile nispeten düşük gerçekleşmiştir.

Tüketici ilgilenimi ölçeğinin alt boyutlarının, tüm markalar için genel ortalaması ilgi 3,25; hedonik değer 3,44; sembolik değer 2,61 olarak gerçekleşmiştir. Apple kullanıcılarının aritmetik ortalamaları incelendiğinde ilgi 3,62; hedonik değer 3,83; sembolik değer 2,63 puanla genel ortalamaların üzerinde oluğu görülmektedir. Samsung kullanıcılarının tüketici ilgilenimi için verdikleri cevaplara göre aritmetik ortalamalar ilgi 3,24; hedonik değer 3,37; sembolik değer 2,67' dir ve genel ortalamaya çok yakındır. Diğer markaları kullanan cevaplayıcıların tüketici ilgilenimine verdikleri cevapların ortalamaları ise düşük düzeyde gözlenmiştir. 
Çalışmanın ana konusunu oluşturan marka aşkına verilen cevaplara göre tüm markaların, marka aşkının aritmetik ortalaması 3,45'tir. Bu sonuca göre, cevaplayıcıların kullandıkları markalara yönelik hislerinin ortalamanın üstünde olduğu söylenebilir. Apple kullanıcıları ise 3,84 ortalama ile markalarını en çok seven kullanıcı grubu konumundadir. Samsung kullanıcilarının ortalaması 3,39'dur ve genel ortalamaya çok yakındır. Bu ortalama değere bakarak Samsung kullanıcılarının da markalarına göreceli olarak aşk beslediği söylenebilir. Diğer markaları kullanan tüketicilerin marka aşkı düzeyi 2,89 ile genel ortalamanın oldukça altındadır.

Sadakat ölçeğinin alt boyutları olan yeniden satın alma ve tavsiye etmenin aritmetik ortalamaları incelendiğinde, tüm markaların aritmetik ortalamalarının sırasıyla 3,60 ve 3,51 olarak gerçekleştiği görülmektedir. Genel olarak bakıldı̆̆ında, cevaplayıcıların kullandıkları markaları tekrar satın alma ve başkalarına tavsiye etme niyetinde olduğu söylenebilir. Apple kullanıcılarının aritmetik ortalamaları tavsiye etme için 4,00; yeniden satın alma için 4,11'dir. Bu sonuçlara göre sadakatin iki boyutunda da Apple kullanıcıları diğerlerinin önünde yer almaktadır. Bu bağlamda Apple'ın kendine sadık müşteriler yaratma konusunda başarıya ulaştığı yorumu yapılabilir. Samsung kullanıcılarının yeniden satın alma $(3,42)$ ve başkalarına tavsiye etme niyetinin $(3,55)$ de iyi düzeyde olduğu söylenebilir.

Cevaplayıcıların memnuniyet ortalamaları incelendiğinde, tüm markaların ortalamasının 3,85 olduğu ve genel olarak kullandıkları markalardan memnun oldukları söylenebilir. Apple kullanıcılarının memnuniyet ortalaması 4,15 gibi yüksek bir rakamdır ve bu kitle kullandıkları markadan en memnun tüketici grubu konumundadır. Samsung kullanıcıları da 3,82 memnuniyet ortalaması ile markalarından memnun olduklarını belirtmişlerdir. Diğer markaları kullanan tüketicilerin ortalaması 2,89 ile genel olarak düşüktür ve Apple ile Samsung'un oldukça gerisinde kalmaktadır.

Cevaplayıcıların kullandıkları akıllı cep telefonu markasının marka imajına verdikleri puanların aritmetik ortalaması genel olarak 3,85'tir. Bu ortalamaya bakarak cevaplayıcıların kullandıkları markaların iyi bir imajı olduğunu düşündükleri söylenebilir. Apple kullanıcıları 4,40 ile markalarının çok iyi bir marka 
imajına sahip olduğunu düşünmektedirler. Samsung kullanıcılarının da 3,74 ortalama ile markalarının iyi bir imaja sahip olduğunu düşündükleri söylenebilir.

\subsection{Geçerlilik ve Güvenirlilik Analizleri}

Bu bölümde ilk olarak ele alınan değişkenlerin faktör yapılarını belirlemek için Doğrulayıcı faktör analizi yapılmıştır. Bunun yanı sıra, geçerlilik için AVE ve Fornell-Larcker Kriter değerleri hesaplanmıştır. Ölçeklerin güvenilirliği için Cronbach'ın Alfa katsayısı ve Composite Reliability (CR) değerleri hesaplanmıştır.

Araştırmada kullanılan ölçeklerin çoğu yabancı kaynaklardan alındı̆̆ı için, Türkçe uygulamasında ölçeklerin doğrulanması gerekmektedir. Bundan dolayı, araştırma ölçekleri ve soruları Doğrulayıcı Faktör Analizi ile sınanmıştır. Tablo 3'te Doğrulayıcı Faktör Analizi sonucunda her bir madde için hesaplanan faktör yükleri görülmektedir.

DFA sonucunda, ölçekleri oluşturan her bir ifadenin (Aşk5 hariç) faktör yüklerinin 0,60'ın üstünde olduğu görülmektedir. Hair, Black, Babin ve Anderson'a göre (2010), DFA'da faktör yüklerinin 0,60' in üstünde olması gerekmektedir. Faktör yüklerinin istenen seviyede çıkması geçerlilik için yeterli değildir. DFA sonucunda uyum iyiliği değerlerine de bakmak gerekmektedir (Özkırış, 2010, s.51). Araştırma kapsamında yapılan DFA sonucunda elde edilen uyum iyiliği endeksleri ve literatürde kabul edilen endeks değerleri Tablo 4'te görülmektedir. Tablo incelendiğinde, değerlerin büyük bir kısmının kabul edilebilir aralıkta olduğu; SRMR değerinin iyi uyum gösterdiği, GFI değerinin ise kabul edilebilir uyumun bir miktar altında kaldığı söylenebilir. Ancak, bazı kaynaklarda GFI değerinin 0,85'in üstünde olması yeterli kabul edilmektedir (Schermelleh-Engel, Moosbrugger ve Müller, 2003). $\mathrm{Bu}$ bulgulardan hareketle, araştırma verisinin kabul edilebilir düzeyde uyum gösterdiği söylenebilir. 
Tablo 3. Doğrulayıcı Faktör Analizi

\begin{tabular}{|c|c|c|c|c|c|}
\hline \multicolumn{3}{|c|}{ İfadeler ve Değişkenler } & Faktör Yükü & $\mathbf{t}$ & $\mathbf{p}$ \\
\hline Güv1 & $<---$ & Marka Güveni & 0,786 & 26,019 & 0,001 \\
\hline Güv2 & $<--$ & Marka Güveni & 0,794 & 22,337 & 0,001 \\
\hline Güv3 & $<---$ & Marka Güveni & 0,783 & 22,704 & 0,001 \\
\hline Güv4 & $<--$ & Marka Güveni & 0,888 & 23,654 & 0,001 \\
\hline Yeni1 & $<--$ & Marka Yenilikçiliği & 0,849 & 27,759 & 0,001 \\
\hline Yeni2 & $<--$ & Marka Yenilikçiliği & 0,871 & 29,235 & 0,001 \\
\hline Yeni3 & $<--$ & Marka Yenilikçiliği & 0,867 & 29,547 & 0,001 \\
\hline Yeni4 & $<--$ & Marka Yenilikçiliği & 0,838 & 27,853 & 0,001 \\
\hline İlgi1 & $<--$ & İlgi & 0,745 & 25,592 & 0,001 \\
\hline İlgi2 & $<--$ & İlgi & 0,909 & 25,036 & 0,001 \\
\hline İlgi3 & $<--$ & İlgi & 0,939 & 25,332 & 0,001 \\
\hline Hed1 & $<---$ & Hedonik & 0,824 & 26,956 & 0,001 \\
\hline Hed2 & $<--$ & Hedonik & 0,929 & 29,946 & 0,001 \\
\hline Hed3 & $<--$ & Hedonik & 0,850 & 27,123 & 0,001 \\
\hline Sem1 & $<---$ & Sembolik & 0,824 & 24,354 & 0,001 \\
\hline Sem2 & $<--$ & Sembolik & 0,872 & 25,250 & 0,001 \\
\hline Sem3 & $<--$ & Sembolik & 0,832 & 26,312 & 0,001 \\
\hline Aşk1 & $<--$ & Marka Aşk1 & 0,865 & 31,261 & 0,001 \\
\hline Aşk2 & $<--$ & Marka Aşk1 & 0,883 & 31,583 & 0,001 \\
\hline Aşk3 & $<--$ & Marka Aşkı & 0,871 & 30,761 & 0,001 \\
\hline Aşk4 & $<---$ & Marka Aşk1 & 0,620 & 18,273 & 0,001 \\
\hline Aşk5 & $<--$ & Marka Aşkı & 0,550 & 15,676 & 0,001 \\
\hline Ysa1 & $<--$ & Yeniden Satın & 0,893 & 39,454 & 0,001 \\
\hline Ysa2 & $<--$ & Yeniden Satın Al & 0,922 & 38,742 & 0,001 \\
\hline Ysa3 & $<--$ & Yeniden Satın Alma & 0,935 & 40,080 & 0,001 \\
\hline Tav1 & $<--$ & Tavsiye Etme & 0,906 & 31,222 & 0,001 \\
\hline Tav2 & $<--$ & Tavsiye Etme & 0,823 & 29,679 & 0,001 \\
\hline Tav3 & $<--$ & Tavsiye Etme & 0,876 & 33,657 & 0,001 \\
\hline Mem1 & $<---$ & Memnuniyet & 0,863 & 31,854 & 0,001 \\
\hline Mem2 & $<---$ & Memnuniyet & 0,855 & 30,232 & 0,001 \\
\hline Mem3 & $<--$ & Memnuniyet & 0,699 & 21,761 & 0,001 \\
\hline Mem4 & $<--$ & Memnuniyet & 0,882 & 32,065 & 0,001 \\
\hline Mem5 & $<--$ & Memnuniyet & 0,889 & 32,587 & 0,001 \\
\hline İmaj1 & $<--$ & Marka İmaj1 & 0,858 & 28,144 & 0,001 \\
\hline İmaj2 & $<--$ & Marka İmaj1 & 0,885 & 30,541 & 0,001 \\
\hline İmaj3 & $<-$ & Marka İmajı & 0,768 & 24,354 & 0,001 \\
\hline İmaj4 & $<--$ & Marka İmaj1 & 0,812 & 26,534 & 0,001 \\
\hline
\end{tabular}

Tablo 4. Doğrulayıcı Faktör Analizi Uyum İyiliği Verileri

\begin{tabular}{cccc}
\hline Uyum Ölçüleri & İyi Uyum & $\begin{array}{c}\text { Kabul Edilebilir } \\
\text { Uyum }\end{array}$ & $\begin{array}{c}\text { Arasstırmada Ortaya } \\
\text { Çıan Değer }\end{array}$ \\
\hline SRMR & $0 \leq$ SRMR $\leq 0,05$ & $0,05 \leq$ SRMR $\leq 0,10$ & 0,048 \\
GFI & $0,95 \leq \mathrm{GFI} \leq 1,00$ & $0,90 \leq \mathrm{GFI}<0,95$ & 0,876 \\
AGFI & $0,90 \leq \mathrm{AGFI} \leq 1,00$ & $0,85 \leq \mathrm{AGFI}<0,90$ & 0,850 \\
NFI & $0,95 \leq \mathrm{NFI} \leq 1,00$ & $0,90 \leq \mathrm{NFI}<0,95$ & 0,928 \\
CFI & $0,97 \leq \mathrm{CFI} \leq 1,00$ & $0,95 \leq \mathrm{CFI}<0,97$ & 0,951 \\
RMSEA & $0 \leq \mathrm{RMSEA} \leq 0,05$ & $0,05<\mathrm{RMSEA} \leq 0,08$ & 0,052 \\
$X^{2} / \mathrm{df}$ & $0 \leq X^{2} / \mathrm{df} \leq 2$ & $2<X^{2} / \mathrm{df} \leq 3$ & 2,928 \\
\hline \multicolumn{4}{c}{ Kaynak: Bayram, N. $(2010)$}
\end{tabular}


Ölçeklerin yapısı belirlendikten sonra, geçerlilik ve güvenirlilik için bazı hesaplamaların incelenmesi gerekmektedir. Güvenirlilik için Cronbach'ın Alfa katsayısı ve CR değerleri kullanılmaktadır. Bu değerlerin 0,70'in üstünde olması istenmektedir (Hair vd., 2010). Alfa katsayıları ve CR değerleri incelendiğinde, tüm değişkenlerin istenilen seviyenin üzerinde değere sahip olduğu görülmektedir. Bu sonuçlar, ölçeklerin güvenilirlik koşullarını sağladığını göstermektedir.

Tablo 5. Cronbach'1n Alfa Katsayısı ve Fornell-Larcker Kriter Değerleri

\begin{tabular}{lccccccccccr}
\hline & Alfa & $\mathbf{1}$ & $\mathbf{2}$ & $\mathbf{3}$ & $\mathbf{4}$ & $\mathbf{5}$ & $\mathbf{6}$ & $\mathbf{7}$ & $\mathbf{8}$ & $\mathbf{9}$ & $\mathbf{1 0}$ \\
\hline (1) Güven & 0,88 & $\mathbf{0 , 8 1}$ & & & & & & & & & \\
(2) Yenilik & 0,91 & 0,542 & $\mathbf{0 , 8 5}$ & & & & & & & & \\
(3) İlgi & 0,89 & 0,499 & 0,408 & $\mathbf{0 , 8 7}$ & & & & & & & \\
(4) Hedonik & 0,89 & 0,491 & 0,409 & 0,578 & $\mathbf{0 , 8 7}$ & & & & & & \\
(5) Sembolik & 0,88 & 0,172 & 0,060 & 0,269 & 0,331 & $\mathbf{0 , 8 4}$ & & & & & \\
(6) Assk & 0,88 & 0,671 & 0,533 & 0,606 & 0,594 & 0,276 & $\mathbf{0 , 7 7}$ & & & & \\
(7) YSA & 0,94 & 0,682 & 0,609 & 0,630 & 0,616 & 0,191 & 0,710 & $\mathbf{0 , 9 2}$ & & & \\
(8) Tavsiye & 0,90 & 0,621 & 0,562 & 0,565 & 0,603 & 0,214 & 0,670 & 0,733 & $\mathbf{0 , 8 7}$ & & \\
(9) Memnun. & 0,92 & 0,699 & 0,578 & 0,476 & 0,544 & 0,168 & 0,677 & 0,733 & 0,741 & $\mathbf{0 , 8 4}$ & \\
(10) İmaj & 0,89 & 0,558 & 0,665 & 0,411 & 0,492 & 0,055 & 0,574 & 0,616 & 0,595 & 0,639 & $\mathbf{0 , 8 3}$
\end{tabular}

Not: Köşegende yer alan koyu renkli değerler, değişkenlerin AVE değerlerinin kareköklerini belirtmektedir.

Tablo 6'da geçerlilik için kullanılan CR, AVE, MSV ve ASV değerleri verilmiştir.

Tablo 6. Geçerlilik Analizi Bulguları

\begin{tabular}{lcccc}
\hline & CR & AVE & MSV & ASV \\
\hline GÜV & 0,89 & 0,66 & 0,61 & 0,39 \\
YEN & 0,92 & 0,73 & 0,54 & 0,32 \\
ILG & 0,90 & 0,75 & 0,40 & 0,26 \\
HED & 0,90 & 0,75 & 0,48 & 0,31 \\
SEM & 0,88 & 0,71 & 0,15 & 0,06 \\
AŞK & 0,88 & 0,59 & 0,62 & 0,46 \\
TAV & 0,94 & 0,84 & 0,63 & 0,46 \\
YSA & 0,90 & 0,76 & 0,67 & 0,44 \\
MEM & 0,92 & 0,71 & 0,67 & 0,44 \\
IMA & 0,90 & 0,69 & 0,54 & 0,35
\end{tabular}

GÜV: Güven; YEN: Marka Yeniliği; TAV: Tavsiye Etme; YSA: Yeniden Satın Alma; AŞK: Marka Aşkı; MEM: Memnuniyet; IMA: İmaj; İLG: İlgi; HED: Hedonik; SEM: Sembolik

Tablo 6'da gösterilen faktör yükleri yakınsak geçerlilik için önemli birer göstergedir. Yakınsak geçerlilik için AVE değerlerinin en az 0,50 olması gerekmektedir (Hair vd., 2010, s.605). Bununla beraber hesaplanan CR değerlerinin, AVE değerlerinden daha büyük olması yakınsak geçerlilik için bir başka kanıt olarak 
kabul edilmektedir (Byrne, 2010). Tablo 10 incelendiğinde tüm ölçeklerin ve boyutların, AVE değerlerinin 0,50'nin üzerinde olduğu görülmektedir. Ayrıca tüm boyutlarda AVE değerinin CR değerinden küçük olması kriteri de gerçekleşmiştir. Tüm bu bulgular ölçek boyutlarının yakınsak geçerliliğinin sağlandığını göstermektedir.

Ayırma geçerliliği (discriminant validity) ise ASV, MSV, AVE ve FornellLarcker Kriter değerleri ile incelenmiştir. Hair ve arkadaşları (2010, s.691) ayırma geçerliliği için, AVE değerinin ASV ve MSV değerlerinden büyük olması gerektiğini belirtmişlerdir. Tablo 10 incelendiğinde, marka aşkı hariç tüm değişkenler bu kuralı sağlamaktadır. Marka aşkı değişkeninin AVE değeri 0,59, MSV değeri 0,62'dir. Aralarında sadece 0,03 gibi nispeten küçük bir fark bulunmaktadır. Aynı kaynağa göre, bir boyutun AVE değerinin karekökünün, diğer boyutlarla arasındaki korelasyonlardan büyük olması gerekmektedir (Fornell-Larcker Kriteri). Tablo 9' da yer alan her bir boyut için AVE değerlerinin karekökleri incelendiğinde, bu değerlerin boyutun diğer boyutlarla olan korelasyonlarından büyük olduğu görülmektedir. Bulunan bu kanıtlar ayırma geçerliliğinin, bu araştırma özelinde sağlandığını ortaya koymaktadır.

\subsection{Araştırma Modelinin Yapısal Eşitlik Modeli ile Test Edilmesi}

Araştırmada kullanılan değişkenlerin birbirleriyle aralarındaki ilişkileri ve modelin geçerliliğini ölçmek amacıyla yapısal eşitlik modeli analizi yapılmıştır.

Tablo 7. Araştırma Modelinin Yapısal Eşitlik Modeli Uyum İyiliği Değerleri

\begin{tabular}{cccc}
\hline $\begin{array}{c}\text { Uyum } \\
\text { Ölçüleri }\end{array}$ & İyi Uyum & $\begin{array}{c}\text { Kabul Edilebilir } \\
\text { Uyum }\end{array}$ & $\begin{array}{c}\text { Araştırmada Ortaya } \\
\text { Çıan Değer }\end{array}$ \\
\hline SRMR & $0 \leq \mathrm{SRMR} \leq 0,05$ & $0,05 \leq \mathrm{SRMR} \leq 0,10$ & 0,0541 \\
GFI & $0,95 \leq \mathrm{GFI} \leq 1,00$ & $0,90 \leq \mathrm{GFI}<0,95$ & 0,879 \\
AGFI & $0,90 \leq \mathrm{AGFI} \leq 1,00$ & $0,85 \leq \mathrm{AGFI}<0,90$ & 0,858 \\
NFI & $0,95 \leq \mathrm{NFI} \leq 1,00$ & $0,90 \leq \mathrm{NFI}<0,95$ & 0,928 \\
CFI & $0,97 \leq \mathrm{CFI} \leq 1,00$ & $0,95 \leq \mathrm{CFI}<0,97$ & 0,952 \\
RMSEA & $0 \leq \mathrm{RMSEA} \leq 0,05$ & $0,05<\mathrm{RMSEA} \leq 0,08$ & 0,051 \\
$X^{2} / \mathrm{df}$ & $0 \leq X^{2} / \mathrm{df} \leq 2$ & $2<\mathrm{X}^{2} / \mathrm{df} \leq 3$ & 2,824 \\
\hline
\end{tabular}

Tablo 7'ye göre araştırma modelinin yapısal eşitlik modeli ile test edilmesi sonucunda ortaya çıkan uyum iyiliği değerleri; SRMR; (0,0541), GFI; $(0,879)$, AGFI; 
$(0,858)$, NFI; (0,928), CFI; $(0,952)$, RMSEA $(0,051)$ ve $X^{2} / \mathrm{df} \quad(2,824)$ olarak hesaplanmıştır. Bulunan bu değerler genel olarak değerlendirildiğinde, araştırma modelinin kabul edilebilir uyum gösterdiği söylenebilir.

Tablo 8. Araştırma Hipotezlerinin Test Sonuçları

\begin{tabular}{cccccc}
\hline Hipotezler & $\begin{array}{c}\text { Bağımsız } \\
\text { Değişkenler }\end{array}$ & $\begin{array}{c}\text { Bağımlı } \\
\text { Değişkenler }\end{array}$ & $\begin{array}{c}\text { Standardize } \\
\boldsymbol{\beta}\end{array}$ & $\mathbf{p}$ & Sonuçlar \\
\hline H1 & Güven & Marka Aşk1 & 0,491 & 0,001 & Desteklendi \\
H2 & Yenilik & Marka Aşk1 & 0,273 & 0,001 & Desteklendi \\
H3 & İlgi & Marka Aşk1 & 0,130 & 0,001 & Desteklendi \\
H4 & Hedonik Değer & Marka Aşk1 & 0,242 & 0,001 & Desteklendi \\
H5 & Sembolik Değer & Marka Aşk1 & $-0,011$ & 0,642 & Desteklenmedi \\
H6 & Marka Aşk1 & Yeniden Satın Alma & 0,891 & 0,001 & Desteklendi \\
H7 & Marka Aşk1 & Tavsiye Etme & 0,875 & 0,001 & Desteklendi \\
H8 & Marka Aşk1 & Memnuniyet & 0,892 & 0,001 & Desteklendi \\
H9 & Marka Aşk1 & Marka İmajı & 0,762 & 0,001 & Desteklendi \\
\hline
\end{tabular}

Tablo 8'de araştırma modelinde gösterilen hipotezlerin test sonuçları yer almaktadır. Buna göre, araştırmada test edilen dokuz hipotezin sekizinin \%99 güven düzeyinde desteklendiği, bir tanesinin ise desteklenmediği görülmektedir. Sembolik değerin marka aşkına etkisinin incelendiği H5 hipotezi bu araştırma özelinde desteklenmemiştir.

\section{SONUÇ VE ÖNERILER}

$\mathrm{Bu}$ araştırma kapsamında akıllı telefon markalarına yönelik marka aşkı düzeyi incelenmiş; güven, yenilik ve tüketici ilgileniminin (ilgi, hedonik değer, sembolik değer) marka aşkı üzerindeki etkisine bakılmış; marka aşkının ise sadakat (tavsiye etme ve yeniden satın alma), müşteri memnuniyeti ve marka imajı üzerinde bir etkisinin olup olmadığı araştırılmıştır. Bulunan sonuçlar 1şı̆̆ında firmalara ve araştırmacılara katkı vereceği düşünülen bazı önerilerde bulunulmuştur.

Araştırmada bulunan sonuçlara göre, marka güveni marka aşkını pozitif yönlü olarak etkilemektedir. Bu sonuç tüketicilerin bir markayla aralarında bağ olabilmesi için öncelikle o markaya güven duymaları gerektiğini göstermektedir. Markalar kendilerine âşık bir tüketici grubu yaratmak istiyorlarsa bu işe önce güven vererek başlamalıdırlar. Akıllı cep telefonu markaları gerek satış öncesi, gerek satış sonrası hizmetleri ile müşterilere güven verebilirler. Çalışmanın bulguları ile aynı doğrultuda Kalyoncuoğlu (2017), müşterilerin markaya duydukları güven ile aşk 
arasında pozitif ve anlamlı bir ilişki olduğunu, Onurlubaş ve Altunışık (2019); Albert ve Merunka (2013); Turgut (2014) ise marka güveninin marka aşkı üzerinde anlamlı bir etkisi olduğunu tespit etmişlerdir.

Araştırma sonuçlarına göre markalar ne kadar yenilikçi olurlarsa kendilerine âşık bir tüketici grubu yaratma şansları da o kadar yükselir. Araştırmaya katılan cevaplayıcıların verdikleri yanıtlar incelendiğinde yenilik yapan, sıradan olmayan, kendini geliştiren markaların daha çok sevildiği tespit edilmiştir. Kendini yenilemeyen, çağa ve teknolojiye ayak uydurmayan markalar zamanla silinip unutulabilirler. Akıllı cep telefonu sektöründe markalar sürekli yeni modeller, yeni özellikler, yeni teknolojiler geliştirmekte ve tüketicilerin hizmetine sunmaktadirlar. Nitekim bu araştırmada da yenilik sorularına verilen aritmetik ortalama genel olarak 3,73 gibi oldukça yüksek bir değerdedir. Çalışmanın bulguları ile aynı doğrultuda Aydın (2016) ile Özbek ve diğerleri (2017) marka yenilikçiliğinin marka aşkı üzerinde pozitif yönde anlamlı bir etkisi olduğunu tespit etmişlerdir. Bu bağlamda araştırma bulgularının literatür ile uyumlu olduğu söylenebilir.

Tüketici ilgileniminin marka aşkına etkisi incelediğinde, bu etkinin ilgi ve hedonik değer boyutunda tespit edildiği; sembolik değer boyutunda ise bulunamadığı görülmektedir. Buna göre, tüketicilerin akıllı cep telefonu ürününü önemli olarak görmeleri, ürüne karşı özel bir ilgi beslemeleri ve üründen zevk almaları durumunda marka aşkı düzeyinin artması beklenmektedir. Öte yandan sembolik değerin marka aşkını etkilememesinin nedeninin tüketicilerin telefonlarıyla bütünleşmesi ve akıllı telefonun sembolik değerine, bu ürün ilk piyasaya sürüldüğü dönemlerdeki kadar önem verilmemesi olduğu düşünülmektedir. Başka bir ifadeyle, akıllı telefonun sembolik değer algısı hala yüksek olmasına rağmen, bunun marka aşkı oluşturacak bir önemde algılanmaması bu etkinin ortaya çıkmamasına neden olabilir. Araştırmanın bulguları ile benzer bir şekilde Hegner ve diğerleri (2017), yüksek ilgilenim düzeyinin marka aşkına sebep olduğunu tespit etmiştir. Çalışmanın bulguları ile aynı doğrultuda Carroll ve Ahuvia (2006) hedonik ürünlerin marka aşkı üzerinde etkisi olduğunu, Huber ve diğerleri (2015) ise hedonik değerin marka aşk1 üzerinde önemli etkilerinin bulunduğunu tespit etmişlerdir. 
Rekabetin giderek artması yeni müşteriler kazanmak kadar, sadakat sağlayıp mevcut müşteriyi elde tutmayı da bir o kadar önemli hale getirmiştir. Araştırmada ortaya çıkan sonuçlar marka aşkının, sadakatin tavsiye etme ve yeniden satın alma boyutlarını etkilediğini göstermektedir. Bu bulguya göre, markalarına âşık olan tüketicilerin sadık olma ihtimalinin de yükselebileceği söylenebilir. Bu sonuçlar, mevcut müşterileri elde tutmak anlamına gelen sadakati geliştirmede marka aşkının ne kadar önemli olduğunu göstermektedir. Çalışmanın sonuçları ile aynı doğrultuda Arslan ve Nur (2018) hazır giyim sektöründe uyguladıkları çalışmada marka aşkı ile yeniden satın alma niyeti arasında pozitif ve anlamlı bir ilişki olduğunu, Fetscherin (2014); Sarkar ve diğerleri (2012); Aydın (2016) ise çalışmalarında marka aşkının yeniden satın alma üzerinde anlamlı ve pozitif yönde bir etkiye sahip olduğunu tespit etmişlerdir. Ayrıca Carroll ve Ahuvia (2006); Albert ve diğerleri (2008); Batra ve diğerleri (2012); Albert ve Merunka (2013); Fetscherin (2014) yapmış oldukları çalışmalarda marka aşkının pozitif ağızdan ağıza pazarlamaya, dolayısıyla tavsiye etmeye pozitif yönde bir etkisinin olduğunu tespit etmişlerdir.

Araştırmada çıkan sonuçlara göre markalar kendilerine âşık tüketiciler yaratırlarsa bu markalara müşteri memnuniyeti, sadakat ve marka imajı olarak geri dönüş sağlayacaktır. Araştırma bulguları markalarına âşık tüketicilerin markalarından diğer müşterilere göre daha fazla memnun kaldı̆̆ını göstermektedir. Bu durum marka aşkı oluşturmanın firmalar açısından oldukça önemli bir strateji olduğu gerçeğini doğrulamaktadır.

İmaj, tüketicilerin markayı düşündükleri zaman zihinlerinde ilk canlanan olgulardan biridir. Şüphesiz her firma, her marka iyi olarak anılmak, hatırlanmak ister. Markalar, tüketicilerin karşısında iyi bir imaj yaratma çabasındadırlar. İyi bir imaj yaratmak, müşteri sadakati sağlamak kadar önemlidir. Araştırma sonuçlarına göre, marka aşkı marka imajını doğrudan etkilemektedir. Bu sonuca dayanarak tüketicilerin markalarına olan aşk düzeyleri arttıkça markanın imajına olan bakışlarının da olumlu yönde artacağı söylenebilir. Çalışmanın bulguları ile aynı doğrultuda Kang (2015), Hindistan'da akıllı telefonlar üzerine yaptığı çalışmada müşterilerin markalarına karşı hissettikleri marka aşkının marka imajı üzerinde pozitif bir etkisi olduğunu tespit etmiştir. 
Marka aşkı yaratmada en önemli unsurlardan biri marka güvenidir. Marka aşkı yaratma çabasında olan firmalar ilk olarak müşterilere güven vererek işe başlamalıdırlar. Güven her sektörde olduğu gibi akıllı cep telefonu sektöründe de çok önemlidir. Müşteri ürünü satın alma öncesinde, alışveriş sırasında ve ürünü aldıktan sonra firmaya, markaya ya da ürüne güven duymak ister. Cep telefonu sektöründe müşteri alışveriş öncesi pazar araştırması yaptığında marka ile ilgili güveneceği şeyler duymak ister. Alışveriş sırasında da satıcı ile görüşürken marka hakkında güven verici şeyler işitmek ister. Akıllı cep telefonu sektöründe satış sonrasında garanti güvencesiyle müşteriye güven verilebilir. Bunlar sağlandığ1 takdirde tüketicinin o markaya duygusal bağ hissetme ihtimali daha da yükselir.

Marka aşkını etkileyen unsurlardan bir diğeri de marka yeniliği kavramıdır. Tüketiciler sıradan olanların yerine yenilik sunanları, kendini geliştirenleri, yerinde saymayanları daha çok tercih eder. Araştırma sonuçlarına göre yenilikçi olan markalar diğerlerine göre daha çok sevilmektedir. Her geçen gün yeni bir cep telefonu modelinin tanıtıldığı günümüzde yenilik yapma konusunda yarış oldukça artmıştır (telefondan telefona şarj aktarma, yapay zekâ, yüz tanıma gibi). Yenilik konusunda bu kadar ileri gidilmişken, marka aşkını yaratmak isteyen firmalar ARGE çalışmalarına daha fazla önem vermelidirler.

Araştırmada tüketici ilgilenimi kavramının ilgi ve hedonik değer boyutlarının marka aşkını etkilediği sonucuna ulaşılmıştır. Bu sonuca göre marka aşkı yaratmak isteyen firmalar pazar araştırmaları yaparak tüketicilerin ilgisini nelerin çekeceğini, onları ne tarz ürünlerin mutlu edeceğini ve haz vereceğini bulmalıdırlar. Müşterilerin ilgisini çekecek ve onlara haz verecek ürünler sunan firmalar, diğerlerine göre daha fazla âşık tüketici kitlesi yaratabilirler.

Rekabet arttıkça markalar arasında müşteri geçişleri de bir o kadar artmıştır. Markalar yeni müşteriler kazanırken bir yandan mevcut müşterilerini kaybedebilirler. Müşterilerinin yeniden aynı markayı tercih etmesini ve çevresindeki insanlara kendi kullandığı markayı kullanmaları konusunda tavsiyede bulunmasını isterler. Bu sebeplerden dolayı mevcut müşteriyi kaybetmek istemeyen firmalar müşteri sadakatine yeterli önemi vermeli ve müşteri sadakatini geliştirecek araştırmalar yapmalıdırlar. Müşteri sadakatini arttıran önemli konulardan biri de 
marka aşkıdır. Marka aşkına gerekli önemi veren, markasına âşık tüketiciler yaratma çabasında olan firmalar müşteri sadakati yaratma konusunda avantajlı konumda olurlar. Araştırmada çıkan sonuçlara göre markasına âşık tüketiciler aynı oranda markasına sadık olurlar. Sadakat yaratmak isteyen firmalar marka aşkına önem verebilirler.

Markalar pazarlama dünyasında uzun süreli bir ömür istiyorlarsa müşterilerini memnun etmelidirler. Müşterilerini memnun eden markalar, marka aşk1 yaratabilir. Memnuniyet oluşturmada marka aşkı çok önemli bir konumdadır. Araştırmadan elde edilen sonuçlara göre marka aşkı, müşteri memnuniyetini olumlu etkilemektedir. Markasına âşık tüketiciler aynı zamanda markasından memnun olmaktadirlar.

Firmalar kendilerini tüketicinin gözünde iyi bir konumda görmek isterler. İyi bir konuma sahip olmak için müşterilerin gözünde güçlü bir marka imaj1 yaratılmalıdır. Markalar bunu başarabilmek için müşterilerine önce güven vermeli, onlara yenilik sunmalı, ilgilerini çekecek ve onlara haz verecek ürünler üretmelidir.

Çalışma kapsamında marka aşkının öncüllerinden marka güveni, marka yeniliği ve tüketici ilgilenimi (ilgi, hedonik değer ve sembolik değer) incelenmiş ve araştırılmıştır. Başka çalışmalarda marka aşkının öncülü olabilecek faklı değişkenler kullanmak farklı sonuçlara ulaşmada yarar sağlayacaktır. Araştırma sürecinde marka aşkının sonuçlarından sadakat (yeniden satın alma ve tavsiye etme), müşteri memnuniyeti ve marka imajı incelenmiştir ve araştırılmıştır. Bu konuda yapılacak başka çalışmalarda marka aşkının etkileyebileceği farklı değişkenler kullanılarak literatüre katkı sağlanabilir. Çalışma zaman ve maliyet kısıtları sebebi ile üniversite öğrencileri üzerinde ve sadece Balıkesir Üniversitesi'ne bağlı Burhaniye Uygulamalı Bilimler Yüksekokulu ve Burhaniye Meslek Yüksekokulu öğrencileri ile yapılabilmiştir. Araştırma modelinin farklı kitleler üzerinde sınanması ile sonuçların geçerliliği artırılabilir. Araştırma örneklemi kolayda örnekleme yöntemi ile belirlenmiştir. Bu nedenle araştırma sonuçlarının genellenmesi doğru değildir. $\mathrm{Bu}$ araştırma modelinin tesadüfi örnekleme yöntemlerinden biri ile seçilmiş bir örneklem üzerinden yeniden test edilmesi araştırma sonuçlarının daha genellenebilir olması sağlanabilir. Çalışma kapsamında marka aşkı ile onun öncülleri ve sonuçları 
akıllı cep telefonu ürünü özelinde değerlendirilmiştir. Aynı öncül ve sonuçlar farklı sektörler ve ürünler özelinde incelenebilir. 


\section{KAYNAKÇA}

Aaker, D. A. (1991). Managing Brand Equity. New York: The Free Press.

Aaker, D. A. (2016). Güçlü Markalar Yaratmak. (Çev. Erdem Demir). İstanbul: MediaCat Kitapları.

Akın, M. (2017), Cep Telefonu Markalarına Yönelik Memnuniyetin Genç Tüketicilerin Marka Sadakatine Etkisi, Ömer Halisdemir Üniversitesi İktisadi ve İdari Bilimler Fakültesi Dergisi Cilt-Sayı: 10(1); 98-110

Akkaya, E. (1999). Marka İmajı Bileşenleri, Otomobil Sektöründe Bir Uygulama. 4. Ulusal Pazarlama Kongresi, 18-20.

Albert, N., Merunka, D., ve Valette-Florence, P. (2008). Brand Love: Conceptualization and Measurement. Australian and New Zealand Marketing Academy Conference.

Albert, N. ve Merunka, D. (2013). The Role of Brand Love in Consumer-Brand Relationships. Journal of Consumer Marketing, 30(3), 258-266.

Altun, Ş. (2007). İnovasyonla Başarıyı Yakalayan Türkler. İstanbul: Mediacat Kitapları.

Arslan, B. ve Nur, E. (2018). Tekrar Satın Alma Niyetinde Marka Aşkı Dokunuşları. 9th International Conference of Strategic Research on Scientific Studies and Education (9th ICoSReSSE), 223-231.

Aşkın, N. ve İpek, İ. (2016). Marka Aşkının Marka Deneyimi İle Marka Sadakati Arasındaki İlişkiye Aracılık Etkisi. Ege Akademik Bakış Dergisi, Cilt.16, Sayı.1, 79-94.

Aydın, H. (2016). Marka Aşkının Değerlendirilmesi: Beyaz Eşya Kullanıcıları Üzerine Bir Araştırma. Tüketici ve Tüketim Araştırmaları Dergisi, 8(2), 125.

Aydın, H. (2017). Marka Güveni, Farkındalığı ve Benlik İmaj Uyumunun Marka Bağlılığına Etkisinde Marka Aşkının Aracılık Rolü. Ege Academic Review, 17(2), 281-293.

Ayvaz, S. (2017). “Aşkın Tüketim Kültürü Üzerinden Yeniden Anlamlandırılması: Markafoni Örneği”. Ankara Üniversitesi İLEF ,Dergisi, 4(1), 149-170.

Ballester, E. D. ve Aleman, J. L. M. (2001). Brand trust in the context of consumer loyalty. European Journal of marketing, 35(11/12), 1238-1258.

Batra, R., Ahuvia, A. ve Bagozzi, R. P. (2012). Brand Love. Journal of Marketing, 76(2), 1-16.

Bauer, H., Heinrich, D. ve Albrecht, C. M. (2009). All You Need is Love: Assessing Consumers' Brand Love. In Proceedings of the American Marketing Association Summer Educators Conference (Vol. 15, No. 2, pp. 252-253). Chicago: American Marketing Association.

Bayram, N. (2010). Yapısal Eşitlik Modellemesine Giriş: Amos Uygulamaları. (1). Bursa. Ezgi Kitabevi.

Bayuk, M. ve Küçük, F. Müşteri Tatmini ve Müşteri Sadakati İlişkisi. Marmara Üniversitesi İktisadi ve İdari Bilimler Dergisi, 22(1), 285-292.

Bergkvist, L. ve Bech-Larsen, T. (2010). Two Studies of Consequencesand Actionable Antecedents of Brand Love. Journal of Brand Management, 17(7), 504-518.

Bostan, S., Acuner, T. ve Yılmaz, G. (2005). Hastane İşletmelerinde Müşteri (Hasta) Beklentileri Araştırması. Sağlık ve Hastane Yönetimi 2. Ulusal Kongresi, Bildiriler Kitabı.

Byrne, M. Barbara (2010). Structural Equation Modeling with AMOS: Basic Concepts, Applications, and Programming. New York: Taylor \& Francis.

Carroll, B. A. ve Ahuvia, A. C. (2006). Some Antecedents and Outcomes of Brandlove. Marketing Letters, 17(2), 79-89. 
Cecere, G., Corrocher, N. and Battaglia, R.D. (2015). Innovation and competition in the smartphone industry: Is there a dominant design? Telecommunications Policy, Vol. 39, pp. 162-175.

Chaudhuri, A. ve Holbrook, M. B. (2002). Product-Class Effects on Brand Commitment and Brand Outcomes: The Role of Brand Trust and Brand Affect. Journal of Brand Management, 10(1), 33-58.

Çakır, V. (2007). Tüketici İlgilenimini Ölçmek. Selçuk Üniversitesi İletişim Fakültesi Akademik Dergisi, 4(4), 163-180.

Doğan, V. ve Özkara, B. Y. (2013). İnternet Ortamında Markaya Güvenin Online Markaların İmajı Üzerindeki Rolü. İnternet Uygulamaları ve Yönetimi Dergisi, 4(2), 5-20.

Elçi, Ş., Karataylı, İ. ve Karaata, S. (2008). Bölgesel İnovasyon Merkezleri: Türkiye İçin Bir Model Önerisi. TUSIAAD Yayınları.

Erdil, T. S. ve Uzun, Y. (2010). Marka Olmak. (2. Baskı). İstanbul: Beta Basım Yayım Dağıtım.

Eskiler, E., Özmen, M. ve Uzkurt, C. (2011). Bilgi Yönetimi Pazar Odaklılık ve Pazarlama Yeniliği İlişkisi: Mobilya Sektöründe Bir Araştırma. Eskişehir Osmangazi Üniversitesi İ̈BF Dergisi, 6(1), 31-69.

Fang, E. (2008). Customer participation and the trade-off between new product innovativeness and speed to market. Journal of Marketing, 72(4), 90-104.

Fetscherin, M. (2014). What Type of Relationship Do We Have with Loved Brands? Journal of Consumer Marketing, 31(6/7), 430-440.

Filieri, R. ve Lin, Z. (2017). The role of aesthetic, cultural, utilitarian and branding factors in young Chinese consumers' repurchase intention of smartphone brands, Computers in Human Behavior, 67, 139-150. https://doi.org/10.1016/j.chb.2016.09.057

Fornell, C. (1992). A National Customer Satisfaction Barometer: The Swedish Experience. The Journal of Marketing, 56(1), 6-21.

Gemlik, N. ve Sığrı, Ü. (2007). Kurum İmajı Analizi ve Bir Belediye Üzerindeki Uygulamanın Değerlendirilmesi. İstanbul Ticaret Üniversitesi Sosyal Bilimler Dergisi, 6(11), 267-282.

Hair, J. F., Black, W. C., Babin, B. J., and Anderson, R. E. (2010). Multivariate Data Analysis: A Global Perspective (7th ed.). Upper Saddle River: NJ.

Hegner, S. M., Fenko, A. ve Teravest, A. (2017). Using the Theory of Planned Behaviour to Understand Brand Love. Journal of Product \& Brand Management, 26(1), 26-41.

Huber, F., Meyer, F., ve Schmid, D. A. (2015). Brand Love in Progress-the Interdependence of Brand Love Antecedents in Consideration of Relationship Duration. Journal of Product \& Brand Management, 24(6), 567-579.

Ismail, A. R. ve Spinelli, G. (2012). Effects of brand love, personality and image on word of mouth The case of fashion brands among young consumers, Journal of Fashion Marketing and Management, 16(4), 386-39.

Kalyoncuoğlu, S. (2017). Markaya Duyulan Güven ile Marka Sadakati İlişkisinde Marka Aşkının Aracılık Rolü: Starbucks Markası Üzerine Bir Araştırma. The Mediating Role of Brand Love in the Journal of Tourism and Gastronomy Studies, Cilt.5, Say1.4, 383-402.

Kandemir, D., Atakan, S. S. ve Demirci, C. (2013). İlgilenim Kavramı ve Türkçe İlgilenim Ölçeklerinin Değerlendirilmesi: Tüketici İlgilenimi, Sürekli İlgilenim ve Satın Alma Kararı İlgilenimi. Iktisat Isletme ve Finans, 28(331), 57-88.

Kang, A. (2015). Brand Love-Moving Beyond Loyalty an Empirical Investigation of Perceived Brand Love of Indian Consumer. Arab Economic and Business Journal, 10(2), 90-101. 
Kapferer, J.N. ve Laurent, G. (1985). Consumer Involvement Profiles: A New Practical Approach to Consumer Involvement. Journal of Advertising Research, 25(6), 48-56.

Kapferer, J.-N., ve Laurent, G. (1993). Further evidence on the Consumer Involvement Profile: Five antecedents of involvement. Psychology \& Marketing, 10(4), 347-355.

Kazemi, A. ve Borandegi, F. (2013). Analyzing the Antecedents and Consequences of Brand Love with a Case Study on Apple Cell Phone Users. International Journal of Academic Research in Business and Social Sciences, 3(11), 320.

Koç, E. (2015). Tüketici Davranışı ve Pazarlama Stratejileri: Global ve Yerel Yaklaşım. (6. Baskı). Ankara: Seçkin Yayıncılık.

Kotler, P. (2017). A'dan Z'ye Pazarlama. (Çev. Aslı Kalem Bakkal). İstanbul: Kapital Medya Hizmetleri.

Külahlı, A. (2016). Tüketici İlgilenimi, Müşteri Memnuniyeti ve Marka Sadakati Arasındaki İlişkiler: Akıllı Telefon ve Parfüm Ürünleri Temelinde Bir Araştırma. Yüksek Lisans Tezi, Balıkesir Üniversitesi Sosyal Bilimler Enstitüsü, Balıkesir.

Lau, G.T., ve Lee, S.H. (1999). Consumers' Trust in a Brand and the Link to Brand Loyalty. Journal of Market-Focused Management, 4, 341-370. https://doi.org/10.1023/A:1009886520142

Leong M. K., Syuhailyb, O. ve Laily P. (2017). Relationship between Consumer Involvement and Consumer Engagement with Consumer Loyalty in Tourism and Hospitality Industry. International Journal of Academic Research in Economics and Management Sciences, 6(4), 72-91.

Liang, C. ve Wang, W. (2008). Do Loyal And More Involved Customers Reciprocate Retailer's Relationship Efforts? Journal of Services Research, 8(1), 63-90.

Lin, L. Y. ve Chen, C. S. (2006). The Influence of the Country-of-Origin Image, Product Knowledge and Product Involvement on Consumer Purchase Decisions: An Empirical Study of Insurance and Catering Services in Taiwan. Journal of Consumer Marketing, 23(5), 248-265.

Luk, S. T. ve Yip, L. S. (2008). The Moderator Effect of Monetary Sales Promotion on the Relationship between Brand Trust and Purchase Behaviour. Journal of Brand Management, 15(6), 452-464.

Martin G. S. ve Brown T. J. (1990). In Search Of Brand Equity: The Conceptualization And Measurement Of The Brand Impression Construct. American Marketing Association, 2, 431-438.

Morgan, R. M. ve Hunt, S. D. (1994). The Commitment-Trust Theory of Relationship Marketing. Journal of Marketing, 58(3), 20-38.

Nemati, A. R., Khan, K. ve Iftikhar, M. (2010). Impact of Innovation on Customer Satisfaction and Brand Loyalty: A Study of Mobile Phones Users in Pakistan. European Journal of Social Sciences, 16(2), 299-306.

Odabaşı, Y. ve Barış, G. (2002). Tüketici Davranışı. İstanbul: MediaCat Kitapları.

Onurlubaş, E. Ve Altunışık, R. (2019). Marka Güveninin Satın Alma Niyeti Üzerindeki Etkisinde Marka Aşkının Aracılık Rolü. Kesit Akademi Dergisi (The Journal of Kesit Academy), Cilt.5, Sayı.1, s. 116135.

Ozansoy, T. Ç. (2010). Tüketicilerin Sosyopsikolojik ve Demografik Özellikleri, İlgilenim, Subjektif Bilgi ve Güven Düzeyine Bağlı Olarak Moda Giysi Pazarının Bölümlendirilmesi. Öneri: Marmara Üniversitesi Sosyal Bilimler Enstitüsü Dergisi, 9(33), 143-152.

Özbek, V., Kutbay, A. Y., Doğan, O. ve Külahll, A. (2017). Antecedents of Brand Love: A Research on Bank Customers. Press Academia Procedia, 3(1), 609-619. 
Özbek, V. ve Külahli, A. (2016). The Effect of Consumer Involvement on Brand Loyalty: A Study on Smart Phone Products. Journal of Management Marketing and Logistics, 3(4), 303-317.

Özkırış, B. (2010). Tüketicinin İmajı ile Marka İmajı Arasındaki Uyumun Marka Sadakati Üzerindeki Etkileri. Doktora Tezi, Gebze Yüksek Teknoloji Enstitüsü, Sosyal Bilimler Enstitüsü, Gebze.

Padgett, D. ve Allen, D. (1997). Communicating Experiences: A Narrative Approach to Creating Service Brand Image. Journal of Advertising, 26(4), 49-62.

Pawle, J. ve Cooper, P. (2006). Measuring Emotion-Lovemarks, the Future Beyond Brands. Journal of Advertising Research, 46(1), 38-48.

Peltekoğlu, F.B. (2007). Halkla İlişkiler Nedir? İstanbul: Beta Yayınları.

Roberts, K. (2005). Lovemarks: The Future Beyond Brands. New York: Power House Books.

Roberts, K. (2010). Lovemarks Etkisi- Tüketici Devrimine Galip Gelmek. (Çev. Çiğdem Aksoy). İstanbul: Hümanist Kitap Yayıncılık.

Salinas, E. A. ve Perez, J. M. P. (2009). Modeling The Brand Extensions Influence On Brand Image. Journal of Business Research, 62, 50-60.

Sarkar, A., Ponnam, A. ve Murthy, B. K. (2012). Understanding and Measuring Romantic Brand Love, Journal of Customer Behaviour, 11(4), 324-347.

Schermelleh-Engel, K., Moosbrugger, H. ve Müller, H. (2003) "Evaluating The Fit of Structural Equation Models: Tests of Significance and Descriptive Goodness-of-Fit Measures", Methods of Psychological Research Online, 8(2), 23-74

Selvi, M. S. (2007). Müşteri Sadakati. Ankara: Detay Yayıncılık.

Sharma, N. ve Patterson, P. G. (2000). Switching Costs, Alternative Attractiveness and Experience as Moderators of Relationship Commitment in Professional, Consumer Services. International Journal of Service Industry Management, 11(5), 470-490.

Shimp, T. A. ve Madden, T. J. (1988). Consumer-Object Relations: A Conceptual Framework Based Analogously on Sternberg's Triangular Theory of Love. Advances in Consumer Research, 15(1): 163-168.

Sternberg, R. J. (1986). A Triangular Theory of Love. Psychological Review, 93(2), 119.

Swaen, V. and Chumpitaz, C. R. (2008). Impact of Corporate Social Resposibility on Consumer Trust. Recherce At Applications on Marketing, 23 (4), 7- 33.

Thomson, M., MacInnis, D. J. ve Whan, P. C. (2005). The Ties that Bind: Measuring the Strength of Consumers' Emotional Attachments to Brands. Journal of Consumer Psychology, 15(1), 77-91.

Torlak, Ö., Doğan, V. ve Özkara, B. Y. (2014). Marka Farkındalığı, Marka İmajı, Markadan Etkilenme ve Markaya Güvenin Marka Bağlılı̆̆ı Üzerindeki Görece Etkilerinin İncelenmesi: Turkcell Örneği. Bilgi Ekonomisi ve Yönetimi Dergisi, 9(1), 147-161.

Traylor, M. B. (1981). Product Involvement and Brand Commitment. Journal of Advertising Research. 21(6), 6-51.

Turgut, M. Ü. (2014). Marka Sevgisinin Marka Güveni, Olumsuz Bilgiye Karşı Direnç ve Tekrar Satın Alma Niyeti Çerçevesinde İncelenmesi. Yüksek Lisans Tezi, Hacettepe Üniversitesi Sosyal Bilimler Enstitüsü, Ankara.

Ulusu, Y. (2016). İlgilenim. Marmara Üniversitesi Öneri Dergisi, Cilt.12, Say1.45, 569-586.

Usta, M. B. ve Faiz, E. (2019). Otomobil Markalarına Duyulan Aşk ile Marka Sadakati Arasındaki İlişkide Marka İmajının Aracılık Rolü. Düzce Üniversitesi Sosyal Bilimler Enstitüsü Dergisi, 9(1), 23-36. 
Usta, R. ve Memiş, S. (2009). Hizmet Kalitesi ve Marka Bağlılı̆̆ı Arasındaki İlişki Üzerine Müşteri Tatmininin Aracılık Etkisi. Atatürk Üniversitesi İktisadi ve İdari Bilimler Dergisi, Cilt. 23, Say1. 4, 87-107.

Uyar, K. ve Lekesizcan S. F. (2017). Markanın Benliği İfade Etmesi ve Sosyal Görünürlügüünün Marka Aşkı ile İlişkisi. Journal Business \& Management Studies: An International Journal, 5(4), 154-171.

Zaichkowsky, J. L. (1985). Measuring The Involvement Construct. Journal of Consumer Research, 12(3), 341-352.

Zeithaml, V.A. Berry, L. L. ve Parasuraman, A. (1996). The Behavioral Consequences of Service Quality, Journal of Marketing, 60, 31-46.

Zhang, Y. (2015). The Impact of Brand Image on Consumer Behavior: A Literature Review. Open Journal of Business and Management, 3(1), 58-62. 